\title{
Taxes and International Risk Sharing
}

\author{
Brendan Epstein * Rahul Mukherjee ${ }^{\dagger} \quad$ Shanthi Ramnath ${ }^{\ddagger}$
}

August 7, 2016

\begin{abstract}
We extend a standard model of international risk sharing to include an empirically plausible distortion: Taxes. The tax-inclusive theory implies, even under full risk sharing, a predictable relationship between consumption growth and the consumption and capital income tax rates, both within and across countries. We find strong empirical evidence in favor of this relationship. While idiosyncratic output fluctuations account for substantially more of cross-country consumption growth variability than do taxes, trends in tax differentials are found to be informative about the dynamic evolution of international risk sharing. In particular, adjusting for capital taxes reveals a marked improvement in risk sharing over the last three decades that is absent in baseline measures. This improvement has been driven by the convergence of average tax rates on capital income across OECD countries towards the United States average capital tax rate.
\end{abstract}

Keywords: International risk sharing; business cycle accounting; risk-sharing wedges; tax convergence; capital taxes.

JEL Codes: F41, F44, H29.

${ }^{*}$ Board of Governors of the Federal Reserve System. E-mail: brendan.epstein@frb.gov.

${ }^{\dagger}$ Corresponding author: IHEID, Geneva. E-mail: rahul.mukherjee@graduateinstitute.ch.

${ }^{\ddagger}$ U.S. Treasury Department, Office of Tax Analysis. E-mail: Shanthi.Ramnath@Treasury.gov. 


\section{Introduction}

A central theoretical prediction of the benchmark international business cycle (IBC) model (Backus et al., 1992) is that risk sharing between countries should be substantial. Furthermore, this international risk sharing should manifest itself through equalization of consumption growth rates across countries. Empirically though, as is well known, consumption growth rates across countries are generally far from being equal. As shown in Table 1, at yearly frequency, cross-country correlations between growth rates of per capita consumption vary from -0.05 to 0.8 , with a mean of $0.42 .{ }^{1}$ Within the context of the benchmark IBC model, this correlation-based evidence points toward a general lack of risk sharing, which is also present at quarterly frequency (see Backus et al., 1992; Chari et al., 2002, among many others). The related prediction that the growth rate of the marginal utility of consumption should not be influenced by country-specific risks is also rejected by the data (Lewis, 1996). Numerous modifications of the benchmark IBC model have been put forward to address this puzzle, with varying degrees of success.

In this paper we revisit the puzzle of empirically low risk sharing by considering a very simple modification to the benchmark IBC model: accounting for taxes on consumption expenditure and capital income. We show that taxes act as a distortion in international financial markets that potentially undermine the true explanatory power of the frictionless benchmark theory. Such a distortion relative to a benchmark model's implications has more recently been coined as a "wedge" in the macroeconomics literature (see, for example, Chari et al., 2007; Prescott, 2004; Ohanian et al., 2008; McDaniel, 2011). Taxes are attractive candidates for such wedges because they are observable and quantifiable, as compared to other black box frictions. We are the first to operationalize the implications of consumption and capital tax wedges for international risk sharing given recently developed time series data on taxes as well as novel time series data on bilateral financial integration. In particular, we use a mix of theory and empirical analysis to address the following question: Do cross-country differences, long run trends, and business cycle frequency fluctuations in consumption and capital taxes matter, and if so, in what way, for understanding international risk sharing or its failure?

The answer to this question is important, as there are intuitive reasons suggesting that accounting for taxes might shed light on the benchmark IBC model's noted empirical anomalies. A simple example with consumption taxes illustrates this point. ${ }^{2}$ International risk sharing is about keeping the ratio of the marginal value of resources constant across countries. In standard models, the ratio of marginal values are proportional to the ratio of consumption growth, so for these models perfect risk sharing implies that consumption growth should be equalized across countries. But standard models do not incorporate taxes. Suppose that country A experiences a reduction in consumption

\footnotetext{
${ }^{1}$ The OECD data used to construct this table span the years 1960 through 2010, and are described later in the paper.

${ }^{2}$ We thank Fabrizio Perri for phrasing this example.
} 
taxes. This reduction in taxes increases the marginal value of transferring resources to country A, so perfect risk sharing would imply that country A should experience faster consumption growth than its partners. To an economist who does not consider taxes, this idiosyncratic variation in consumption growth rates would appear as a violation of risk sharing. But when taxes are considered, this idiosyncratic variation in fact represents quite the opposite: It is the efficient response of international capital flows to a variation in fundamentals (taxes).

Our analysis shows that introducing taxes into the standard IBC framework of Backus et al. (1992) implies that international risk sharing is reflected by a monotonic relationship between international consumption growth, consumption taxes, and capital taxes instead of the usual equalization of consumption growth rates across countries. This monotone relationship is a simple consequence of proportional taxes affecting a model's optimality conditions. Intuitively, differences in consumption taxes affect the implicit relative prices of consumption across countries even in simple environments where the real exchange rate would otherwise be unity, while differences in asset income taxes create incentives to deviate from perfect insurance. Our model has testable implications that we bring to the data. ${ }^{3}$ Note that any exploration of international risk sharing and taxes, especially capital taxes, must by necessity also take into account the role of international financial integration. ${ }^{4}$ Thus, empirical measures of the degree of multilateral and bilateral financial integration of countries play a central role in our analysis.

Our analysis yields three main results. The first of these results obtains from relating our tax-inclusive model's implications to regression-based tests of international risk-sharing à la Lewis (1996), which essentially run a horse race between taxes and country idiosyncratic risk, where risk is proxied by per capita GDP growth. In the data, as implied by the model, there is a statistically and economically significant relationship between consumption growth rates and consumption and capital taxes. In particular: An increase in a country's relative consumption tax growth and/or relative capital income tax growth reduces that country's relative consumption growth. Yet, taxes alone cannot explain the extent to which consumption growth rates are not equalized across countries since macroeconomic aggregates, proxied by per capita GDP growth, explain substantially more of the variance of per capita consumption growth than do taxes.

Second, from the perspective of a business cycle accounting framework (see, for example, Chari et al., 2007), we introduce a novel measure of the degree of international risk sharing at any point in time in the form of a risk-sharing wedge. We define risk-sharing wedges as the extent to which

\footnotetext{
${ }^{3}$ We use a panel of 15 OECD countries for the period 1960-2010 using: yearly tax data from McDaniel (2009) on consumption and capital taxes; yearly consumption and working-age population (ages 15-64) data from the OECD; and yearly empirical measures of financial integration, amongst which stand out a novel one that we construct using confidential data from the Bank of International Settlements.

${ }^{4} \mathrm{~A}$ large theoretical literature suggests that tax rates on mobile factors such as capital should be related to financial integration due to tax competition between countries. Conversely, Coeurdacier (2009) shows that taxes on capital income can to some extent explain (the lack of) financial cross-holdings between countries, which is an often-used measure of de facto financial integration. Thus, financial integration may be an omitted variable that drives both risk sharing and tax rates, especially on capital.
} 
consumption growth rates across countries are not equalized, including or excluding taxes. We then argue that the inclusion of consumption and capital taxes in such a wedge provides a clearer evaluation of how international risk sharing has evolved over time compared to a baseline wedge that does not take these taxes into account. Indeed, accounting for taxes suggests that risk sharing has increased over time broadly in line with increases in financial integration. Yet, absent taxes, when brought to the data the baseline risk-sharing prediction from IBC models tends to suggest, unintuitively, no notable relationship between risk sharing and financial integration. We show that this trend behavior of the level of risk sharing, i.e., the risk-sharing wedge, is driven by the convergence of the levels of capital taxes in our sample of OECD countries to that of the United States.

Third, motivated by this trend behavior of our tax-inclusive risk-sharing wedge, we explore the evolution of capital tax rates across the world and relate it to the process of financial integration that has occurred over the last several decades. We find that while most countries' capital tax rates have converged to that of the United States, the tax rate differentials between these other countries have remained roughly constant. As such, our analysis suggests that the United States has acted as a Stackelberg leader in the setting of capital taxes, with most other countries taking the role of followers. This, in turn, has driven cross-country convergence (towards better risk sharing with the United States) in the tax-inclusive model's implied measure of risk sharing. Our estimates suggest that the median country in our sample experienced a decline of approximately 5.4 percentage points in its capital tax rate differential with the United States over the years 1970-2010 as a result of the process of financial integration. Concurrently, the tax-inclusive risk-sharing wedge for the median country vis-à-vis the United States declined by approximately 7.4 percentage points. In comparison, the baseline risk-sharing wedge that does not take taxes into account declined only 1.8 percentage points in the same period. Thus adjusting for consumption and capital taxes, especially the latter, indicates an improvement in risk sharing that is roughly 4 times larger than the baseline case.

This paper brings together three broad strands of literature in international finance, macroeconomics, and public finance. The first pertains to international consumption risk sharing. The second is related to taxes as wedges in business cycles models. And the third is the literature at the confluence of macroeconomics and public finance that deals with optimal taxation in open economies. By introducing a novel measure of risk sharing in the form of a wedge, and relating its evolution to broad trends in capital taxes across the world, we integrate these three strands that have, quite surprisingly, remained separate until now.

The first strand of literature is exemplified by papers such as Backus et al. (1992, 1994), Backus and Smith (1993), Baxter and Crucini (1995), Stockman and Tesar (1995), Chari et al. (2002), Kehoe and Perri (2002), and Corsetti et al. (2008), among many others, that has sought theoretical explanations for the risk-sharing puzzle. ${ }^{5}$ In the context of this literature, our results should be

\footnotetext{
${ }^{5}$ Artis and Hoffmann (2008) provide an excellent survey. The main conclusion of this literature is that the consumption correlation anomaly is notoriously difficult to solve in the absence of enforcement frictions in international
} 
interpreted as evidence that theoretical models that rely on fluctuations in average tax rates, or fiscal factors in general, are unlikely to provide a complete resolution to the consumption risk-sharing puzzle. At the same time, accounting for consumption and capital taxes is indeed important for arriving at a correct metric against which the relative success or failure of any one explanation for the risk-sharing puzzle should be compared.

As related to the second strand of literature, labor taxes have recently been considered as a possible reason for the marginal product of labor differing from the marginal rate of substitution of consumption for leisure at any given point in time, i.e., the labor wedge (for instance, Prescott, 2004; Ohanian et al., 2008; McDaniel, 2011). In a recent contribution, Karabarbounis (2014b) shows that when parameters of a home production sector are estimated to generate tax-adjusted labor wedges that mimic their empirical counterparts, the standard IBC model with complete asset markets can match some key stylized facts of the data, including that output is more correlated than consumption across countries. Our analysis of the role of consumption and capital taxes in consumption risk-sharing, which uses a business cycle accounting approach and regression-based tests of risk sharing, is complementary to the labor-wedge analysis of Karabarbounis (2014b). ${ }^{6}$

The third strand of literature is exemplified by a series of papers by Enrique Mendoza and co-authors (Mendoza et al., 1994; Mendoza and Tesar, 1998, 2005; Mendoza et al., 2013), among many others. These papers explore tax competition in an international macroeconomic framework. A recent contribution that is related to our work is Coeurdacier et al. (2012), who solve an optimal capital taxation problem when capital is mobile and assets across the world are imperfect substitutes. Our paper also contributes to the large empirical literature on this topic (see Slemrod, 2004; Zodrow, 2010, for example). We provide a more complete survey of this body of work in a later section of our paper.

Methodologically, we are closest to the recent literature on business cycle accounting pioneered by Chari et al. (2007), as well as the older and larger literature that examines empirical measures and tests of risk sharing. To the first, our contribution lies in introducing and documenting the evolution of a novel measure of risk sharing in the form of the wedge between consumption growth

financial markets or strong wealth effects of domestic shocks. Since the framework from which our risk-sharing tests are derived abstracts from both of these complications, it is not surprising that we reject the null of perfect risk sharing. An important empirical insight from this literature is that unobserved factors influencing the measured stochastic discount factor and omitted sources of exogenous or endogenous fluctuations can lead to misleading conclusions about the degree of risk-sharing. Some prominent examples include exogenous preference shocks (Stockman and Tesar, 1995), the presence of non-traded goods in the consumption bundle (Backus and Smith, 1993), non-additivity of leisure and consumption in the utility function (Lewis, 1996), sticky prices (Chari et al., 2002), inflation differentials (Hoffmann, 2008), and the role of expectations (Engel and Rogers, 2009). Our empirical contribution, thus, is to explore the role that consumption and capital taxes may play as an additional source of omitted variation confounding empirical inferences about risk sharing made off otherwise standard international macroeconomic models.

${ }^{6}$ Karabarbounis (2014b) adjusts the level of labor wedges across countries using the labor and consumption tax data from McDaniel (2009), which we also utilize. He notes that time variation in taxes is not relevant for explaining the cyclical properties of the labor wedge, while the level adjustment due to taxes is crucial. These findings are analogous to our conclusions from regression-based tests of risk sharing when capital and consumption taxes are incorporated into the benchmark IBC model, and our risk-sharing wedge analysis. 
across countries. ${ }^{7}$ To the second, we add a comprehensive analysis of a hitherto unexplored source of country specific risk, namely consumption and capital taxes. ${ }^{8}$

The rest of the paper is organized as follows. Section 2 integrates taxes into a standard decentralized IBC model and derives key testable predictions relating consumption growth rates and taxes. Section 3 describes the data we use. Section 4 describes our regression-based methodology and presents results. Section 5 uses a business cycle accounting measure to map the long-term evolution of risk sharing and examines the relationship between this measure, financial integration, and cross-country convergence in capital taxes. Finally, Section 6 concludes.

\section{Theory}

Consider the household's problem in the canonical single-good IBC model (see Backus et al., 1992) augmented with taxes on consumption expenditures and asset income. The representative household in country $i$ maximizes the discounted sum of utilities:

$$
\sum_{t=0}^{\infty} \sum_{s^{t}} \beta^{t} \pi\left(s^{t}\right) U\left(C_{i}\left(s^{t}\right), H_{i}\left(s^{t}\right)\right),
$$

choosing sequences $\left\{C_{i}\left(s^{t}\right), H_{i}\left(s^{t}\right), B_{i}\left(s_{t+1} \mid s^{t}\right)\right\}_{t=0}^{\infty}$, where $C_{i}$ is consumption, $H_{i}$ is labor hours, $B_{i}$ is the total payoff from one-period contingent real bonds that pay out in units of the common world final consumption good, $\beta$ is the discount factor, and $\pi\left(s^{t}\right)$ is the period 0 probability of any particular history $s^{t} .{ }^{9}$ The maximization is subject to the sequence of budget constraints

$$
\begin{aligned}
\left(1+\tau_{i}^{c}\left(s^{t}\right)\right) C_{i}\left(s^{t}\right) & +\sum_{s_{t+1} \in \mathbb{S}} Q\left(s_{t+1} \mid s^{t}\right) B_{i}\left(s_{t+1} \mid s^{t}\right)=\left(1-\tau_{i}^{h}\left(s^{t}\right)\right) W_{i}\left(s^{t}\right) H_{i}\left(s^{t}\right) \\
& +\left(1-\tau_{i}^{k}\left(s^{t}\right)\right) B_{i}\left(s^{t}\right)+\left(1-\tau_{i}^{k}\left(s^{t}\right)\right) \Pi_{i}\left(s^{t}\right)+T_{i}\left(s^{t}\right)
\end{aligned}
$$

In the budget constraint, $W_{i}$ is the wage rate, $Q_{i}\left(s_{t+1} \mid s^{t}\right)$ is the bond price, and $T_{i}$ is a lump sum transfer made by the government. The terms $\tau_{i}^{c}, \tau_{i}^{h}$, and $\tau_{i}^{k}$ are proportional taxes on consumption expenditures, labor income, and asset income (from physical capital and contingent bonds),

\footnotetext{
${ }^{7}$ In a recent paper Backus et al. (2016) interpret wedges in frictionless IBC models as being the byproduct of endogenous variation in Pareto weights in a model with recursive preferences.

${ }^{8}$ Since the seminal work of Cochrane (1991), Mace (1991) and Townsend (1994), a vast literature testing risk sharing at the state and country level has developed, as exemplified by Lewis (1996), Asdrubali et al. (1996), Imbs (2006), Artis and Hoffmann (2008), Flood et al. (2012), among many others. Recent papers in this literature have documented how the degree of risk sharing, as captured by regression-based tests, has evolved over time. The thrust of these papers has been to reconcile the surge in financial globalization in the last two decades with the surprising lack of evidence in favor of improved risk sharing. Explanations have centered around still existent financial frictions and the statistical properties of underlying risks.

${ }^{9}$ We use standard notation to describe the uncertainty that creates incentives for international risk sharing. At each time $t$, the economy is in state $s_{t} \in \mathbb{S}$, where $\mathbb{S}$ is the set of possible states of the world. The sequence of events until date $t$ is denoted by the history $s^{t}$. A household observes the history $s^{t}$, and forms expectations on the future state $s_{t+1}$.
} 
respectively. ${ }^{10}$

Since we are mainly interested in the implications of taxes on international risk-sharing - which plays out exclusively through the asset Euler equations of the representative agent in each country - we only focus on the first-order conditions pertaining to bonds. ${ }^{11}$ The Euler equation for the holdings of the contingent bond in country $i$ is given by

$$
Q\left(s_{t} \mid s^{t-1}\right)=\beta \pi\left(s_{t} \mid s^{t-1}\right) \frac{U_{C i}\left(s^{t-1}, s_{t}\right)}{U_{C i}\left(s^{t-1}\right)} \frac{\left(1+\tau_{i}^{c}\left(s^{t-1}\right)\right)}{\left(1+\tau_{i}^{c}\left(s^{t}\right)\right)}\left(1-\tau_{i}^{k}\left(s^{t}\right)\right) \quad \forall s^{t} .
$$

Equation 2 implies a risk-sharing condition across countries $i$ and $j$ that should hold for each time $t$ and history $s^{t}$. Equating the right hand side of this equation for any country pairs $i$ and $j$ gives us, $\forall s^{t}$ and $i \neq j$,

$$
\frac{U_{C i}\left(s^{t-1}, s_{t}\right)}{U_{C i}\left(s^{t-1}\right)} \frac{\left(1+\tau_{i}^{c}\left(s^{t-1}\right)\right)}{\left(1+\tau_{i}^{c}\left(s^{t}\right)\right)}\left(1-\tau_{i}^{k}\left(s^{t}\right)\right)=\frac{U_{C j}\left(s^{t-1}, s_{t}\right)}{U_{C j}\left(s^{t-1}\right)} \frac{\left(1+\tau_{j}^{c}\left(s^{t-1}\right)\right)}{\left(1+\tau_{j}^{c}\left(s^{t}\right)\right)}\left(1-\tau_{j}^{k}\left(s^{t}\right)\right) .
$$

We henceforth suppress the state-dependent notation in favor of time subscripts, wherever possible, for simplicity. Assuming isoelastic preferences of the form $U\left(C_{i, t}\right)=\frac{C_{i, t}^{1-\gamma}}{1-\gamma}$, Equation 2 implies a monotone relationship between consumption growth, consumption tax growth, and capital income taxes in country $i$ along any equilibrium path with a given schedule of tax rates:

$$
\Delta C_{i, t}=\frac{1}{\gamma} \ln \left[\frac{\beta \pi\left(s^{t}\right)}{Q\left(s^{t}\right)}\right]-\frac{1}{\gamma} \Delta\left(1+\tau_{i, t}^{c}\right)+\frac{1}{\gamma} \ln \left(1-\tau_{i, t}^{k}\right)
$$

Above, $\Delta A_{i, t}=\ln \left(A_{i, t}\right)-\ln \left(A_{i, t-1}\right)$ is the growth rate for any variable $A_{t}$ pertaining to country $i$. Focusing on the last two terms in Equation 4, consumption growth over the previous period is lower with higher consumption and capital income taxes in period $t$. The intuition for this relationship is as follows. Higher growth in consumption taxes between periods $t-1$ and $t$ increases the intertemporal relative price of consumption at time $t$, lowering consumption growth. At the same time, a higher capital income tax rate at time $t$ lowers the after-tax returns to savings, thereby reducing the incentive to shift consumption from period $t-1$ to $t$ and lowers consumption growth.

\footnotetext{
${ }^{10}$ Note that the capital tax is imposed on the asset income $B_{i}\left(s^{t}\right)$ from bonds and not on the value of bond holdings $\sum_{s_{t+1} \in \mathbb{S}} Q\left(s_{t+1} \mid s^{t}\right) B_{i}\left(s_{t+1} \mid s^{t}\right)$. We assume that profits, $\Pi_{i}\left(s^{t}\right)$ from the ownership of physical capital are taxed at the same capital income tax rate at the firm level and that firms take it into account when making their dividend payments. This assumption is meant as a realistic simplification (further details are given later, when we describe the tax data that we use to operationalize the model). The household takes the optimal after-tax dividend $\left(1-\tau_{i}^{k}\left(s^{t}\right)\right) \Pi_{i}\left(s^{t}\right)$ as given in its budget constraint. Thus the capital tax influences the household's problem only through its decision on how many contingent bonds to buy. An alternative is to assume that households make the capital accumulation decision themselves and rent it out to firms at the capital rental rate. This specification leaves our main risk-sharing equation unchanged. See the supplementary appendices for details.

${ }^{11}$ The optimality conditions for the firm's problem, or investment and labor taxes are not directly relevant to the derivation of the cross-country risk-sharing conditions and are hence omitted for conciseness. All our conclusions are robust to the inclusion of these other taxes in the analysis (see an earlier draft of this paper, Epstein et al., 2014, for additional details).
} 
Both effects are proportional to the elasticity of intertemporal substitution, $\frac{1}{\gamma}$. In the absence of taxes, Equation 4 implies that consumption growth in country $i$ should not be influenced by idiosyncratic country risk. This observation forms the basis of the tests of risk sharing we implement later. $^{12}$

Equation 3, in turn, implies the following relationship between consumption growth for any pair of countries $i$ and $j$ :

$$
\Delta C_{i, t}-\Delta C_{j, t}=-\frac{1}{\gamma}\left[\Delta\left(1+\tau_{i, t}^{c}\right)-\Delta\left(1+\tau_{j, t}^{c}\right)\right]+\frac{1}{\gamma}\left[\ln \left(1-\tau_{i, t}^{k}\right)-\ln \left(1-\tau_{j, t}^{k}\right)\right] .
$$

Equation 5 says that in the absence of taxes or when tax regimes coincide (in terms of growth rates of consumption taxes and levels of capital taxes), countries should have the same growth rate of consumption. This corresponds to the definition of perfect risk sharing, or the prediction of perfectly correlated consumption growth rates, of the benchmark IBC model. However, when tax regimes are unequal the country with relatively low consumption tax growth or capital tax level enjoys higher consumption growth. Intuitively, differences in consumption tax growth affect the implicit relative prices of consumption across countries, while differences in asset income taxes create further incentives to deviate from equalization of consumption growth rates. Equation 5 formalizes the intuition behind the example provided in the introduction. As in Equation 4, the effects of both taxes are proportional to the elasticity of intertemporal substitution, $\frac{1}{\gamma} .13$

From a business cycle accounting perspective, Equation 3 can be written for countries $i$ and $j$ as a "risk-sharing wedge" that captures the extent to which, in levels, the tax-inclusive model's risk-sharing condition fails to hold empirically. This risk-sharing wedge approach is akin to the business cycle accounting framework (see Chari et al., 2007) used in recent papers, such as Prescott (2004), Gali et al. (2007), Ohanian et al. (2008), McDaniel (2011), and Karabarbounis (2014a,b), to study the behavior of the labor wedge (the extent to which the marginal rate of substitution of consumption for leisure differs from the marginal product of labor) across time. To the best of our knowledge, the implementation of this approach with consumption and capital taxes in the context of international risk sharing is a novel contribution of our paper.

Taking the ratio of the left and right hand sides of Equation 3, we define three "risk-sharing wedges" between countries $i$ and $j$ at time $t$ as follows. The all-tax-inclusive risk-sharing wedge is defined as

$$
\Gamma_{A, t}^{i j} \equiv \frac{\frac{U_{C i, t}}{U_{C i, t-1}} \frac{\left(1+\tau_{i, t-1}^{c}\right)}{\left(1+\tau_{i, t}^{c}\right)}\left(1-\tau_{i, t}^{k}\right)}{\frac{U_{C j, t}}{U_{C j, t-1}} \frac{\left(1+\tau_{j, t-1}^{c}\right)}{\left(1+\tau_{j, t}^{c}\right)}\left(1-\tau_{j, t}^{k}\right)},
$$

\footnotetext{
${ }^{12}$ In addition, consumption growth also depends on the ratio $\frac{\pi\left(s^{t}\right)}{Q\left(s^{t}\right)}$ that summarizes aggregate, undiversifiable risk, as well as a time-invariant component determined by the discount factor $\beta$. Ceteris paribus, higher $\beta$ or more patience implies higher consumption growth.

${ }^{13}$ We assume that consumption and labor are separable in the utility functions. We consider non-additive labor in the supplementary appendices. Our results are insensitive to this feature of the model for reasons explained in that appendix.
} 
the consumption-tax-inclusive wedge is defined as

$$
\Gamma_{\mathrm{C}, t}^{i j} \equiv \frac{\frac{U_{C i, t}}{U_{C i, t-1}} \frac{\left(1+\tau_{i, t-1}^{c}\right)}{\left(1+\tau_{i, t}^{c}\right)}}{\frac{U_{C j, t}}{U_{C j, t-1}} \frac{\left(1+\tau_{j, t-1}^{c}\right)}{\left(1+\tau_{j, t}^{c}\right)}},
$$

and the baseline wedge (without any taxes) defined as

$$
\Gamma_{\mathrm{B}, t}^{i j} \equiv \frac{\frac{U_{C i, t}}{U_{C i, t-1}}}{\frac{U_{C j, t}}{U_{C j, t-1}}},
$$

where the "A", "B", and "C" subscripts in $\Gamma_{t}^{i j}$ stand for "all-tax-inclusive", "baseline" and "consumptiontax-inclusive", respectively. While $\Gamma_{A, t}^{i j}$ and $\Gamma_{C, t}^{i j}$ arise from our analysis, $\Gamma_{B, t}^{i j}$ is a product of the canonical (or baseline) model of international risk sharing without taxes.

In contrast to the canonical model, once taxes are accounted for perfect international risk sharing need not imply equalization of consumption growth rates. Indeed, note that if the theoretical risksharing condition implied by the model in levels holds exactly at every point in time between countries $i$ and $j$, then $\Gamma_{A, t}^{i j}=1 \forall t$. On the other hand, in the context of the canonical model (i.e., absent taxes) Equation 8 implies that if there is perfect risk sharing then $\Gamma_{B, t}^{i j}=1$ holds. Therefore, assuming isoelastic utility, to the extent that the tax-inclusive model is correct, then $\Gamma_{A, t}^{i j}=1 \neq \Gamma_{B, t}^{i j}$ implies that perfect risk sharing between countries $\left(\Gamma_{A, t}^{i j}=1\right)$ is not necessarily inconsistent with the growth rate of consumption between these two countries being different $\left(\Gamma_{B, t}^{i j} \neq 1\right)$.

A clarifying comment on our measure of risk sharing, $\Gamma_{A, t}^{i j}$, is helpful. In this measure, the ratio of marginal utilities is scaled by the various taxes present in the model. Notice that we would derive a similar expression if we were to consider scaling shocks to utility (for instance shocks to the discount factors), in which case the ratio of marginal utilities would be scaled by the preference shocks. This parallel raises the question of the correct measure of risk sharing. If we were to consider preference shocks, then the scaled ratios of marginal utilities clearly are the relevant measure that a planner would consider. Things are more subtle when considering taxes. As taxes are not structural preferences but instead a source of distortions, a social planner unconstrained in the tools at her disposal would aim for perfect risk sharing without distortions, which corresponds to the measure $\Gamma_{B, t}^{i j}=1$. If, however, the planner cannot affect the taxes she aims for constrained risk sharing that corresponds to the measure $\Gamma_{A, t}^{i j}=1$.

\section{Data}

We focus our analysis on 15 OECD countries for which extensive time series data on taxes (discussed below) are available: Austria, Australia, Belgium, Canada, Finland, France, Germany, Italy, 
Japan, Netherlands, Spain, Sweden, Switzerland, the United Kingdom, and the United States. Furthermore, because time series data on taxes are only available at yearly frequency, our analysis is at that frequency as well. In particular, given limitations on the availability of time series data on taxes, our analysis spans the years 1960 through 2010 for all countries except Australia and Japan. For these two countries the analysis spans 1960 through 2008 per the availability of tax data.

We use data from various sources in order to operationalize the model. Publicly available cross-country data on consumption, output, and the working-age population (ages 15-64) are taken from the OECD. ${ }^{14}$ In particular, the data on consumption and output is from the OECD database VPVOBARSA (this is the OECD acronym for data in volume estimates, fixed purchasing power parities, OECD reference year 2005, annual levels, seasonally adjusted in millions of US dollars). In all the analyses that follow, we work with per capita consumption and output by normalizing these series using each country's respective working age population. ${ }^{15}$

Our country-specific consumption and capital tax data are from McDaniel (2009) and publicly available on her website. ${ }^{16}$ These average tax rates are calculated using national accounts data and a methodology analogous to that used by Mendoza et al. (1994) and Carey and Rabesona (2002). ${ }^{17}$ In broad terms, the consumption tax rate is derived as the ratio of government revenue collected from consumption to total taxable consumption expenditures (household final consumption expenditure net of revenue collected from taxes levied on consumption expenditure). The capital tax rate is the ratio of government revenue from taxing capital (the sum of total capital tax revenue collected from households, direct taxes on corporations, and the share of taxes on production and imports that represents property taxes paid by entities other than households) to capital taxable income (the capital-share weighted difference between gross domestic product and taxes on production and imports minus subsidies, net of gross operating surplus earned by the government). Adding gross operating surplus earned by the government back into the measure of capital taxable income delivers a measure of the sum of operating surplus earned by corporations, the capital share of operating surplus earned by private unincorporated enterprises, and operating surplus earned by the government. ${ }^{18}$

\footnotetext{
${ }^{14}$ Available at stats.oecd.org.

${ }^{15}$ Our conclusions remain unchanged if we use total instead of per capita consumption and output. These results are not reported.

${ }^{16}$ The tax series are available at www.caramcdaniel.com.

${ }^{17}$ In representative agent contexts, Mendoza et al. (1994) suggest that average tax rates derived from national accounts can be useful to represent the marginal tax rates faced by a representative agent. Several papers by Enrique Mendoza and his coauthors have utilized tax data in calibrated dynamic models of international tax competition (Mendoza and Tesar, 1998, 2005; Mendoza et al., 2013). Recent papers such as Karabarbounis (2014b) and Ragan (2013) have used the data from McDaniel (2009).

${ }^{18}$ See McDaniel (2009) for a more detailed description on the calculation of each tax rate.
} 


\subsection{Measures of Financial Integration}

For reasons detailed later in the paper, we make use of three measures of financial integration. The first two of these measures span the years 1970 through 2010 and are fairly standard. One of them is the Chinn-Ito index of de jure financial openness that is described in detail in Chinn and Ito (2006). The second one is a measure of the financial openness of a country constructed using data on total foreign assets and liabilities from Lane and Milesi-Ferretti (2007). Following a large literature, the financial openness ratio of country $i$ to the rest of the world at time $t, \mathbb{I N T}_{i, t}$, is defined as:

$$
\mathbb{N T}_{i, t} \equiv \frac{F O R A S S E T S_{i, t}+F O R L I A B S_{i, t}}{Y_{i, t}},
$$

the ratio of the sum of total foreign assets $\left(F O R A S S E T S_{i, t}\right)$ and foreign liabilities $\left(F O R L I A B S_{i, t}\right)$ to $\operatorname{GDP}\left(Y_{i, t}\right) \cdot{ }^{19}$

Another portion of our analysis uses a third bilateral measure of financial integration constructed using data from the Bank for International Settlements (BIS). In particular, for all countries in our sample we use locational data on the external positions of reporting banks vis-à-vis individual countries and vis-à-vis all sectors. These data are in millions of US dollars and reveal the amount of banking financial claims of one country over another. These BIS data are available publicly on their website, but only for a relatively short time horizon at the time of writing. ${ }^{20}$ However, we are able to access confidential data from the BIS on bilateral financial claims for a majority of each of the years 1978 through 2010 for the pairwise country combinations in our analysis. We use these data in conjunction with the publicly available cross-country data on nominal GDP from the OECD database CPCARSA (this is the OECD acronym for millions of US dollars, current prices, current purchasing power parities, annual levels, seasonally adjusted) to construct bilateral indices of financial integration for the countries in our analysis.

We use the BIS data to construct a measure of bilateral de facto financial connectedness. This measure, which we henceforth refer to as $\mathbb{F}_{i j, t}$, is equal to the sum of financial claims of banks resident in country $i$ over country $j\left(f_{i \rightarrow j, t}\right)$, and financial claims of banks resident in country $j$ over country $i\left(f_{j \rightarrow i, t}\right)$, divided by the sum of these countries' nominal GDP $\left(Y_{i, t}\right.$ and $\left.Y_{j, t}\right)$ :

$$
\mathbb{F}_{i j, t} \equiv \frac{f_{i \rightarrow j, t}+f_{j \rightarrow i, t}}{Y_{i, t}+Y_{j, t}}
$$

In line with the rest of the data used in our paper, this ratio is at yearly frequency. Furthermore, the fact that in currency terms this ratio is unitless allows us to use it within analyses involving real variables. More motivation for our index of bilateral financial integration is provided in a later

\footnotetext{
${ }^{19}$ All three variables are measured in current USD. The two stock variables in the denominator are measured as of Dec 31 and hence converted to USD at the end-of-period exchange rate, while GDP in current USD is converted from domestic currency using the period-average exchange rate. See Lane and Milesi-Ferretti (2007) for more details.

${ }^{20}$ At http://www.bis.org/statistics/bankstats.htm.
} 
section. Summary statistics for all variables are reported in Tables 1 and 2 in the supplementary appendices.

\section{Taxes and Consumption Growth}

In this section, we investigate whether the structural relationship implied by our theory exists in the data and if it affects regression-based tests of risk sharing. In particular, we use Equations 4 and 5, that relate consumption growth to taxes, to derive two alternative regression-based tests following Lewis (1996). Both of these regression-based tests exploit the idea that the asset Euler equations as well as the risk-sharing conditions between country pairs place restrictions on the estimated coefficients in a regression of country $i$ 's consumption growth, or their difference, on idiosyncratic country variables.

We allow for an unobserved preference shock $b_{i, t}$ in country $i$, so that utility for consumption in country $i$ is $U\left(C_{i, t}\right)=b_{i, t} \frac{C_{i, t}^{1-\gamma}}{1-\gamma}$, as well as a country fixed effect, $\alpha_{i}$, to pick up time-invariant country characteristics. Replacing the state notation with a subscripted $t$, Equation 4 can then be rewritten as

$$
\Delta C_{i, t}=\alpha_{i}+\alpha_{t}+\theta_{1} \Delta\left(1+\tau_{i, t}^{c}\right)+\theta_{2} \ln \left(1-\tau_{i, t}^{k}\right)+\psi X_{i, t}+\epsilon_{i, t}
$$

where $\epsilon_{i, t}=\frac{1}{\gamma} \Delta b_{i, t}+\epsilon_{i, t}^{\prime}$ is a composite error term. The term $\alpha_{t}$, which depends on the asset price $Q\left(s^{t}\right)$, and hence aggregate world consumption at time $t$ (see Equation 4), can be interpreted as a time fixed effect in a country-year panel regression. $X_{i, t}$ is a country $i$ specific idiosyncratic variable. The economic interpretation of Equation 11 is that the consumption of an individual country depends on aggregate world consumption (which is equal to aggregate world output) but not on idiosyncratic country variables. The implication is that $\psi=0$ for any time varying idiosyncratic country $i$ variable $X_{i, t}$ not appearing directly in the Euler equation.

Similarly, Equation 5 can be rewritten as:

$$
\begin{array}{r}
\Delta C_{i, t}-\Delta C_{j, t}=\alpha_{i j}+\theta_{1}^{\prime}\left[\Delta\left(1+\tau_{i, t}^{c}\right)-\Delta\left(1+\tau_{j, t}^{c}\right)\right]+\theta_{2}^{\prime}\left[\ln \left(1-\tau_{i, t}^{k}\right)-\ln \left(1-\tau_{j, t}^{k}\right)\right] \\
+\psi^{\prime}\left[X_{i, t}-X_{j, t}\right]+\epsilon_{i j, t}
\end{array}
$$

where $\alpha_{i j}$ is a country pair fixed effect, and $\epsilon_{i j, t}=\frac{1}{\gamma}\left[\Delta b_{i, t}-\Delta b_{j, t}\right]+\epsilon_{i j, t}^{\prime}$ is a composite error term. ${ }^{21}$ Perfect risk-sharing then implies $\psi^{\prime}=0$.

We take logarithms of the yearly series for per capita consumption and gross consumption tax rates and time-difference to construct the data for estimating Regressions 11 and 12. The capital tax rate is used in its logarithms without taking its time difference, corresponding to the derived

\footnotetext{
${ }^{21}$ An earlier draft of this paper (Epstein et al., 2014) showed that the fixed effects $\alpha_{i}$ and $\alpha_{i j}$ can be explicitly derived from Equations 4 and 5 if we allow for time-invariant differences across countries, such as different discount rates. For example, in the case of different discount rates $\beta_{i}$ and $\beta_{j}$ in countries $i$ and $j$, the fixed effects can be represented as $\alpha_{i}=\frac{1}{\gamma} \ln \left[\beta_{i}\right]$ and $\alpha_{i j}=\frac{1}{\gamma}\left(\ln \left[\beta_{i}\right]-\ln \left[\beta_{j}\right]\right)$.
} 
structural equations. The idiosyncratic country risk variable $X_{i, t}$ in our benchmark regressions is per capita GDP growth in country $i$ between periods $t-1$ and $t$. Note that the coefficients of interest in both these regressions would remain unchanged if instead we used the deviation of national per capita GDP growth from world per capita GDP growth (as is customary in this literature), due to the time fixed effect in Equation 11 (which absorbs world GDP growth in period $t$ ) and the country differencing of contemporaneous variables in Regression 12 (where world GDP growth cancels out).

\subsection{Benchmark Results: 1960-2010}

Tables 2 and 3 summarize the results from estimating Regressions 11 and 12, and show that the empirical relevance of the tax-inclusive theory is supported by the data. Estimation of Equation 12 requires us to choose a benchmark country $j$ for each country $i$. In the spirit of standard IBC analysis, for instance Backus et al. (1992), where results are presented with the United States as the benchmark country that interacts with "the rest of the world" we set the United States as country $j$. Thus, in the following sentences "relative" refers to the average country $i$ relative to the United States. $^{22}$

Note from the second row of Tables 2 and 3, columns 2 and 4, that the coefficient on consumption tax growth and relative consumption tax growth have the sign predicted by the expressions in Equations 4 and 5, respectively, regardless of whether capital taxes are included in the regressions. That is, an increase in domestic consumption tax growth is associated with lower consumption growth in Table 2, and the same is true for relative quantities in Table 3. While the log-level of capital taxes has the wrong sign in Table 2 (third row, columns 3 and 4), it is not statistically significant. However, the difference in the log-level of capital taxes across countries has the correct sign in Table 3 (third row, columns 3 and 4) and is statistically significant, implying that an increase in relative capital income taxes (which reduces $1-\tau^{k}$ in relative terms) reduces relative consumption growth. ${ }^{23}$ As is the case with the consumption tax, in the case of the capital tax the point estimates are roughly the same whether the consumption tax is included or not in the regression.

The estimated marginal effect of per capita GDP growth is larger than the marginal effects of a change in the growth rate of the consumption tax and the level of the capital tax. To get a sense of their relative magnitudes, we use the coefficient estimates from Tables 2 and 3, along with the standard deviations of the corresponding variables (reported in Table 1 of the supplementary appendices) to make some back-of-the-envelope calculations. A one standard deviation increase

\footnotetext{
${ }^{22}$ Alternative choices of benchmark countries as well as using all possible country pairs leaves the conclusions from our regressions unchanged.

${ }^{23}$ We perform panel unit root tests for all the series, which are found to be stationary with the exception of the capital tax rate which enters Equation 11 in its logarithms without differencing (as used in the regression corresponding to Table 2). Thus the negative and insignificant coefficient on the log-level in Table 2 should in any case be interpreted with caution. However the difference of capital taxes across a country pair, which enters Equation 12 is stationary (as used in the regression corresponding to Table 3).
} 
in per capita GDP growth is associated with a nearly a 0.8 standard deviation increase in per capita consumption growth. In comparison, a one standard deviation increase in $\Delta\left(1+\tau^{c}\right)$ is associated with only a 0.06 standard deviation decline in per capita consumption growth. In turn, a one standard deviation increase in relative per capita GDP growth is roughly consistent with a 0.75 standard deviation increase in relative per capita consumption growth. In comparison, one standard deviation increases in relative $\Delta\left(1+\tau^{c}\right)$ and $\ln \left(1-\tau^{k}\right)$ are associated with, respectively, a 0.09 standard deviation decline and increase in per capita consumption growth. These calculations show that per capita GDP growth explains much more of the variability in per capita consumption growth than do taxes.

All told, regardless of issues pertaining to relative magnitudes, we conclude that consumption growth responds predictably to the growth rate of consumption taxes and the log level of capital taxes as implied by our theory. Since a large literature, surveyed in detail later, points to tax rates

being related to international financial integration through the mechanism of tax competition, we next consider whether these empirical results are robust to controlling for different measures of financial integration.

\subsection{The Role of Financial Integration (1970-2010 and 1978-2010)}

International financial integration is perfect by definition in our theoretical complete markets model. In reality, countries are imperfectly financially integrated with each other and their degree of integration has varied over our sample period in both de jure (see Chinn and Ito, 2006) and de facto (see Lane and Milesi-Ferretti, 2007) terms. We show in an appendix that the relationship between consumption growth and taxes predicted by the theory also holds (in expected values) when financial markets are incomplete. Since the degree of financial integration is arguably a proxy for the degree of market completeness at the international level, our results should therefore hold for all levels of financial integration, and not controlling for it in our regressions is not a major concern in this respect. However, a large literature in public finance and international macroeconomics, which we detail later in the paper, suggests that tax rates should be correlated with financial integration with causality running in both directions. Since risk sharing ought to be directly influenced by the degree of financial integration, taxes in our benchmark results could just be acting as a proxy for financial integration. We thus test the sensitivity of the benchmark results of the previous section to controlling for financial integration.

To do so, we use two of the three measures of financial integration described earlier as individual regressors and interacted with our measures of idiosyncratic risk:

$$
\Delta C_{i, t}=\alpha_{i}+\alpha_{t}+\theta_{1} \Delta\left(1+\tau_{i, t}^{c}\right)+\theta_{2} \ln \left(1-\tau_{i, t}^{k}\right)+\psi_{1} X_{i, t}+\psi_{2} \mathbb{I N} \mathbb{T}_{i, t}+\psi_{3} X_{i, t} \times \mathbb{I N T}_{i, t}+\epsilon_{i, t}
$$




$$
\begin{array}{r}
\Delta C_{i, t}-\Delta C_{j, t}=\alpha_{i j}+\theta_{1}^{\prime}\left[\Delta\left(1+\tau_{i, t}^{c}\right)-\Delta\left(1+\tau_{j, t}^{c}\right)\right]+\theta_{2}^{\prime}\left[\ln \left(1-\tau_{i, t}^{k}\right)-\ln \left(1-\tau_{j, t}^{k}\right)\right] \\
+\psi_{1}^{\prime}\left[X_{i, t}-X_{j, t}\right]+\psi_{2}^{\prime} F_{i j, t}+\psi_{3}^{\prime}\left[X_{i, t}-X_{j, t}\right] \times \mathbb{F}_{i j, t}+\epsilon_{i j, t} .
\end{array}
$$

These specifications are similar in spirit to Lewis (1996) and much of the subsequent empirical literature on risk sharing. Since Equation 13 tests the sensitivity of the consumption growth rate of a single country to idiosyncratic shocks vis-à-vis the rest of the world, we use $\mathbb{I N} \mathbb{T}_{i, t}$, which measures the financial openness of a country to the rest of the world. This series is available for the years 1970-2010. For Equation 14, which is in bilateral terms, we use our measure of bilateral financial connectedness $\mathbb{F}_{i j, t}$, which is only available for the years 1978-2010. The results are reported in Tables 4 and 5 respectively. For comparison with the benchmark results, Table 2 should be compared to Table 4, and Table 3 should be compared to Table 5 .

In comparing results, it should be kept in mind that the sample periods for the regressions differ due to the availability of our financial integration measures. In particular, while the benchmark tables use data from 1960-2010, Tables 4 and 5 use data from 1970-2010 and 1978-2010 respectively. For Equation 13, the fourth row of Table 4 (columns 2 and 4) shows that the results for the consumption tax are consistent in sign (and roughly magnitude) with Table 2 , but these coefficients are not significant at conventional levels. In turn, the fifth row of Table 4 (columns 3 and 4) shows that the log level of the gross capital tax rate is also of the same sign as in the corresponding benchmark case shown in Table 2 (and roughly of the same magnitude). Recall that the negative sign of this coefficient is the opposite of what is predicted by the theory, but these point estimates were not statistically significant in the benchmark case (Table 2), while in Table 4 these point estimates are indeed significant but only at the $10 \%$ level. In turn, comparing results between Table 3 and Table 5: the sign and significance of the consumption tax are consistent with each other as well as with the predictions of the theory; and capital taxes are of the correct sign and significant in Table 3 while they are of the incorrect sign but insignificant in Table 5 . The analysis implies that the results pertaining to capital taxes are the most sensitive when financial integration is controlled for. This is consistent with the well-known idea in public finance that capital taxes are strongly influenced by the process of financial integration.

While the financial openness measure is itself significant in all the specifications, it does not have a clear interpretation in the framework of risk-sharing regressions. The interaction term with our idiosyncratic risk measure, however, does: If financial openness led to more risk sharing, this should show up as a negative and significant interaction term. While the interaction coefficient estimate is indeed negative it is not statistically significant. This result is consistent with the findings of the large literature on the (lack of) international risk sharing surveyed in Kose et al. (2009).

\subsection{Discussion}

The overall picture that emerges from our analysis is that the relationship between consumption growth and taxes predicted by the theory holds in the data: Fluctuations in taxes lead to predictable 
changes in consumption growth within and between countries. In particular, countries with lower consumption tax growth rates or capital tax levels relative to the United States (as noted before, the choice of benchmark country does not affect our results), enjoy significantly higher consumption growth on average. Thus, the simple inclusion of taxes improves the fit to the data of the benchmark model of international risk sharing.

The predictable variations in consumption growth induced by taxes, however, turn out to be small when compared to those induced by idiosyncratic shocks to per capita output. In other words, the international risk sharing puzzle remains in this case, since taxes do not explain much of the variance in consumption growth both within and across countries, in comparison to per capita GDP growth.

Given the results thus far, we conclude that since taxes are a statistically significant determinant of consumption growth and its differentials across countries, they should be controlled for when evaluating the performance of individual theories or frictions that purport to explain international risk sharing. Of note, in terms of point estimates, Table 4 suggested an intuitive relationship between international financial integration and improved risk sharing. Accordingly, in what follows, we use the business cycle accounting framework that allows us to derive risk-sharing wedges in order to further explore the relationship between financial integration and risk sharing.

\section{Financial Integration, Taxes, and the Evolution of Risk Sharing}

As noted in our earlier discussion, from a business cycle accounting perspective, Equations 6, 7 and 8 are informative about the level of risk sharing between countries, and thus can be used to chart the evolution of risk sharing over time. Since taxes distort risk sharing at each point in time, this issue is related to, but also in itself of separate interest relative to, the impact of taxes on consumption growth rates that is the standard metric of the average degree of risk sharing over time. In the spirit of the labor wedges literature (for instance Prescott, 2004; Ohanian et al., 2008; McDaniel, 2011) we start with a graphical analysis of the evolution of risk sharing over time. To do so, we plot our measures $\Gamma_{B, t}^{i j}, \Gamma_{C, t}^{i j}$, and $\Gamma_{A, t}^{i j}$ from 1960 onwards, operationalizing the wedges using isoelastic preferences of the form $U\left(C_{i}\right)=\frac{C_{i}^{1-\gamma}}{1-\gamma}$. We use a value of $\gamma=2$, which is the value that Backus et al. (1992), among many others, use in their benchmark calibration. Furthermore, in all cases, we take the United States as country $j$ per the notation in Equations 6-7. As before, the choice of the United States as country $j$ is in the spirit of standard IBC analysis.

The dashed black line in Figure 1 plots the risk-sharing wedge for all countries assuming away all taxes. This is the baseline risk-sharing wedge, $\Gamma_{B, t}^{i j}$, that is the focus of canonical models of international risk sharing. In all cases, this risk-sharing wedge generally oscillates about 1, which suggests that in level terms the baseline wedge derived from the canonical model's risk-sharing condition has been trendless while being subject to relatively short lived deviations (in some cases, 
though, of considerable magnitude) around unity. The solid blue line in Figure 1 plots the risksharing wedge with "consumption taxes only", $\Gamma_{\mathrm{C}, t}^{i j}$, yielding similar conclusions as the case in which consumption taxes are omitted. We conclude that without controlling for taxes, or controlling only for consumption taxes, risk-sharing wedges generally oscillate around 1. The implication from these graphs is that international risk sharing has not improved over time, which is consistent with the accepted wisdom that risk sharing measured by consumption correlations or risk-sharing regression coefficients has not been improved by the large increases in financial integration that took place over the last several decades. At the risk of oversimplifying the conclusions of a voluminous literature, this failure has generally been interpreted as there not being enough financial integration (see Bai and Zhang, 2012; Bengui et al., 2013) or volatility in the current account (Bai and Zhang, 2010) to achieve perfect risk sharing period by period.

In turn, Figure 2 again plots the risk-sharing wedge for each country (the solid black lines, measured on the left vertical axes), but now accounting for both capital and consumption taxes, i.e., $\Gamma_{A, t}^{i j}$ (defined in Equation 6). For illustration, it also plots the commonly used Chinn-Ito index (see Chinn and Ito, 2006, 2008) of de jure financial openness of a country, but as a ratio of its value for the United States (the dashed green lines, measured on the right vertical axes). The difference compared to the no-tax and consumption-tax-only cases depicted in Figure 1 is stark. Indeed, inspection of Figure 2 shows that in all cases except Germany and Japan the tax-inclusive risk-sharing wedge broadly exhibits a trend decline across countries. In particular, over time risksharing wedges generally approach unity from above. At the same time, the relative Chinn-Ito index has generally risen across countries. One interpretation of Figure 2 is that at the same time that countries' overall financial openness has risen, risk sharing of all other countries in our sample with the United States has risen as implied by the behavior of the full risk-sharing wedge. ${ }^{24}$ In contrast, absent taxes and, in particular, absent capital taxes (Figure 1) the risk-sharing condition would suggest that financial liberalization is largely irrelevant for the long-term evolution of risk sharing. Thus, controlling for taxes, and especially capital taxes, appears to be important for a correct assessment of trends in risk sharing relative to trends in financial openness.

How have capital taxes affected the decline in risk-sharing wedges? One possible answer to this question, which emerges from our previous discussion, is purely mechanical: The decline in the risk-sharing wedge reflects the convergence of capital tax rates of a majority of the large economies of the world to that of the United States. Inspecting the expression for the all tax-inclusive wedge

$$
\Gamma_{A, t}^{i j} \equiv \frac{\frac{U_{C i, t}}{U_{C i, t-1}} \frac{\left(1+\tau_{i, t-1}^{c}\right)}{\left(1+\tau_{i, t}^{c}\right)}\left(1-\tau_{i, t}^{k}\right)}{\frac{U_{C j, t}}{U_{C j, t-1}} \frac{\left(1+\tau_{j, t-1}^{c}\right)}{\left(1+\tau_{j, t}^{c}\right)}\left(1-\tau_{j, t}^{k}\right)},
$$

\footnotetext{
${ }^{24}$ In terms of interpreting results, it is important to note that the Chinn-Ito index is a de jure measure of restrictions on cross-border financial transactions compiled from the IMF's Annual Report on Exchange Arrangements and Exchange Restrictions (AREAER), and is not correlated with our tax series purely by construction. The Chinn-Ito index is also a measure of overall financial openness, but not of pairwise financial connectedness as our measure $\mathbb{F}_{i j, t}$.
} 
and comparing Figures 1 and 2, it is clear that the downward trend in the wedges has been driven

by the term $\frac{1-\tau_{i}^{k}}{1-\tau_{\mathrm{US}}^{k}}$ (recall that country $j$ is the United States). In particular, the decline in the risk-sharing wedge must be driven by a decline of the ratio $\frac{1-\tau_{i}^{k}}{1-\tau_{\mathrm{US}}^{k}}$, and hence by a decline of the United States capital tax rate relative to the other countries in our sample. Although not shown in the interest of brevity, operationalizing the full risk-sharing wedge using other countries in our sample as country $j$ does not suggest nearly as strong of a negative association between risk-sharing wedges and overall financial openness as Figure 2 does. ${ }^{25}$ In the following section, we delve deeper into this issue by exploring the evolution of international capital tax rates relative to the United States, as well as other bilateral country pairs.

\subsection{Financial Integration and the Evolution of Taxes}

In light of our earlier findings, in this section we relate the evolution of relative international capital tax rates to the process of international financial integration. To set the stage, we first provide an overview of the large literature in public finance and macroeconomics that deals with the international taxation of capital income, and its relationship with financial integration. We then present our empirical findings and relate them to the existing literature.

\subsubsection{Background}

Early models of tax competition imply that in small, open economies the burden of taxation should shift from mobile to immobile factors (see Gordon and Hines, 2002, for a survey of the literature). Thus, to the extent that capital is freely mobile across countries, competition should theoretically trigger a race to the bottom, where the optimal tax rate on capital is driven to zero. Studies measuring capital mobility across countries conclude that capital is indeed mobile and that its mobility has increased over time (Zodrow, 2010). In particular, Zodrow (2010) notes that pre-existing barriers to capital flows have declined significantly over time due to deregulation of financial markets and advances in technologies that helped increase capital mobility. Numerous papers in international finance have also noted that both de facto and de jure measures of financial openness and integration have improved in the last decades. Yet, empirically, a race to the bottom in corporate tax rates never materialized, and, in reality, many countries derive revenue by taxing returns to both capital and labor.

Although tax revenue from capital is not zero, many studies have found evidence that competition in corporate tax rates exists (Zodrow, 2010; Devereux, 2007; Hines, 2007). These studies often focus on declines in statutory corporate tax rates that occurred over time. For example, Devereux et al. (2008) look at whether increased competition among OECD countries led to the observed decline in statutory corporate tax rates during the 1980s and 1990s by developing a the-

\footnotetext{
${ }^{25}$ We provide these additional figures in the supplementary appendices.
} 
oretical model with testable implications regarding strategic international competition in taxes on corporate income. They find strong evidence that countries compete over the statutory tax rate to attract mobile profit, but only weak evidence that countries compete over the tax on capital income in order to attract capital. More specifically, Devereux et al. (2008) argue that the empirical reduction in tax rates is almost entirely explained by competition induced by the relaxation of capital controls. Tax competition, on the other hand, appears to have had less of an impact on average corporate tax rates (Zodrow, 2010). ${ }^{26}$ In turn, Grubert (2001) measures average corporate tax rates using foreign taxes and net income reported on Form $5471{ }^{27}$ In that paper, OLS results with changes in average corporate tax rates as the dependent variable find that small, open, and relatively poor countries experienced the largest decline in effective tax rates on corporations. ${ }^{28}$ These results are interpreted as evidence of tax competition in average tax rates.

Earlier, and in similar spirit, Mendoza and Tesar (2005) note that the integration of European financial markets in the early 1980s resulted in harmonized indirect taxes but large differences in factor taxes (i.e., no race-to-the-bottom materialized). They show that such results can be explained by a neoclassical general equilibrium model of tax competition subject to joint externalities of tax policy operating through fiscal solvency, relative prices, and wealth distribution. More recently, though, Coeurdacier et al. (2012) note that, theoretically, a race-to-the-bottom of cross-country capital taxation depends on the very strong assumption that claims on physical capital in different countries are perfect substitutes. Their work relaxes this assumption and leads to the result of nonzero capital taxes in the long run. In particular, Coeurdacier et al. (2012) consider the situation in which capital returns are stochastic and international investment portfolio decisions are endogenous. Amid this environment of uncertainty, cross-country risk sharing implies that investors optimally hold domestic and foreign capital stocks even if they have different expected returns net of taxes, and governments have an incentive to finance part of their expenditures at the expense of foreign capital holders. As a result, a race-to-the-bottom does not materialize and capital taxes remain positive.

In addition to competition, Slemrod (2004) argues that domestic forces making corporate taxation less desirable could also be converging across countries. Slemrod investigates the relationship between domestic factors in addition to a country's openness on both statutory and average corporate tax rates. Openness is measured in two distinct ways: (1) trade volume relative to GDP; and (2), following Sachs and Warner (1995), a dummy variable indicating openness. The results provide suggestive evidence of domestic influences on corporate tax rates, namely the use of the corporate

\footnotetext{
${ }^{26}$ See Zodrow (2010) and Gordon and Hines (2002) for a more complete survey of the literature.

${ }^{27}$ Form 5471 is required by the IRS to be filed by certain US citizens and residents who are officers, directors, or shareholders in certain foreign corporations. The Form requires the filer to report detailed information for taxation purposes including, though not limited to, foreign taxes and net income. See https://www.irs.gov/pub/irspdf/i5471.pdf for more information.

${ }^{28}$ The author also reports results where changes in statutory tax rates is the dependent variable; however, as noted in Slemrod (2004), comparable results on whether changes in statutory rates fell more so for small, open, and relatively poor countries are not reported.
} 
tax rate as a backstop to the individual income tax. However, the results also provide insight into the role of competition on corporate taxation. In pooled OLS regressions, openness is negatively correlated with statutory rates. Although the sign remains negative when country-specific fixed effects are included, the coefficient on openness is no longer statistically significant. For both types of regression specifications (pooled OLS and fixed effects), no statistically significant relationship is found to exist between openness and average corporate tax rates. The author concludes these results provide some, though not definitive, evidence on the role of competitive pressures on corporate taxation.

Of greater direct relevance for our findings, Devereux and Loretz (2013) provide a survey of the literature on different models of tax competition that have emerged over the past twenty years. By relaxing the assumption of perfect competition from earlier models, a number of new testable predictions were generated. For example, assuming asymmetric Bertrand competition as in Bucovetsky (1991) implies that small countries set lower tax rates. On the other hand, Gordon (1992) models competition using a Stackelberg framework in which a large country sets higher tax rates and smaller countries react by setting tax rates up to the levels of the large country's rate. ${ }^{29}$ Consistent with Gordon (1992), Altshuler and Goodspeed (2015) provide empirical evidence on the particular form that global tax competition takes on by testing the existence of a Stackelberg leader, which is assumed to be either the United States, the United Kingdom, or Germany, and followers are assumed to be Nash competitors with one another. Reaction functions are then estimated where the coefficients of interest provide responses with respect to the Stackelberg leader and with respect to other Nash competitors. Overall, the authors find that European countries behaved as if the United States was a Stackelberg leader in setting corporate taxes after the Tax Reform Act of 1986 (TRA86), but not before. Furthermore, the evidence fails to support the United Kingdom or Germany as Stackelberg leaders.

It follows that, in broad terms, the literature on taxation and financial openness suggests that greater financial openness should be associated with some sort of capital tax competition and therefore some sort of capital tax convergence, although a race to the bottom would be a special case of such convergence. We now proceed to examine what the tax data we use from McDaniel (2009) has to say regarding this issue.

\subsubsection{Analysis on Tax Convergence}

Turning now to the empirical behavior of the capital tax series that we use in our analysis, Figure 3 plots the level of the average tax rate on capital for all countries in our sample from 1960 through 2010. The figure illustrates that the United States is the only country that exhibits a strong downward trend in capital taxes over the sample period, while all other countries generally exhibit

\footnotetext{
${ }^{29}$ Table 1 of Devereux and Loretz (2013) provides a more detailed summary of past tax competition models and their resulting testable predictions
} 
rising capital tax rates. Particularly striking is the fact that over the sample period the United States' capital tax rate decreased from a very high rate, around $40 \%$, to roughly $25 \%$ and by the end of the sample period other countries' capital tax rates are generally in line with that of the United States. The graph thus depicts international convergence in capital tax rates, and is in line with findings from previous literature on corporate taxes that imply the United States has acted as a Stackelberg leader. In particular, our graphical evidence suggests that over the period in question, capital tax rates across major advanced economies were converging to the United States capital tax rates from below. That is, most of the countries in our sample were raising their capital tax rate to the level of the United States.

Figure 4 shows the same phenomenon as above in a slightly different way. It plots, for the same period, the absolute value of the capital tax rate differential between country $i$ and the United States (black solid line), and the absolute value of the deviation of the capital tax wedge of country $i$ (with respect to the United States) from unity (green dashed line). These are, respectively $\left|\tau_{i}^{k}-\tau_{\mathrm{US}}^{k}\right|$ and $\left|\frac{1-\tau_{i}^{k}}{1-\tau_{\mathrm{US}}^{k}}-1\right|$. Both of these quantities are measured on the left vertical axes. It also plots the ratio of the Chinn-Ito index of country $i$ to that of the United States (blue dotted line) on the right vertical axes. Taken together, Figures 3 and 4 provide prima facie evidence that as financial integration increased over time, a process of international capital tax rate convergence took place amid the United States lowering its tax rate and most other countries raising their tax rates over the period 1960-2010.

The preceding figures suggest that the early years of our sample were associated with larger declines in the tax rate difference. To verify this visual impression, we report in Table 6 the mean and standard deviation of the absolute value of the capital tax rate differential between country $i$ and $j,\left|\tau_{i}^{k}-\tau_{\mathrm{j}}^{k}\right|$. We do this for the United States as country $j$ (first two columns), as well as for all bilateral country pairs where country $j$ is not the United States (last two columns). In the spirit of the analysis in Slemrod (2004), these summary statistics are calculated for each five year interval starting in 1961 and ending in 2010. The means of the tax rate suggest the following. First, capital tax convergence has mostly been a phenomenon of the countries in our sample vis-à-vis the United States, not among themselves. In fact, the difference in capital tax rates between the other countries in our sample remained quite stable over the same period. Thus, convergence to roughly similar capital tax rates did not lead to convergence among bilateral country pairs: Such differences were already quite low, compared to the differences between these countries and the United States at the beginning of the sample period, and remained stable. Second, the evolution of the means shows that the time path of capital tax convergence to the United States has been uneven. Most of the convergence appears to have taken place in the period 1970-1985, which is consistent with the interpretation that the United States acted as a Stackelberg leader in setting taxes on the mobile factor of production, capital, during this period. ${ }^{30}$

\footnotetext{
${ }^{30}$ Note that this period is before TRA86, and thus our suggestive evidence does not fit the timing of United States tax leadership found in the more elaborate empirical analysis of Altshuler and Goodspeed (2015). However, as
} 
Was this capital tax convergence to the United States related to the process of international financial integration of these countries? To test this hypothesis we run a simple panel regression similar to the specifications we estimated earlier:

$$
\tau_{i-U S, t}^{k}=\alpha_{i}+\theta_{I N T} \mathbb{I N} \mathbb{T}_{i, t}+\epsilon_{i, t},
$$

where $\alpha_{i}$ is a country fixed effect, the dependent variable is $\tau_{i-U S, t}^{k}=\left|\tau_{i}^{k}-\tau_{\mathrm{US}}^{k}\right|$, and the independent variable is $\mathbb{N N T}_{i, t}$, the financial integration measure derived from Lane and Milesi-Ferretti (2007) that was already used in our earlier analyses. We use this measure because it starts in 1970, whereas our bilateral measure based on BIS data starts only in 1978 when the process of convergence was well underway. The point estimate of $\theta_{I N T}$ is -0.011 , and it is statistically significant at the $1 \%$ level. ${ }^{31}$ As noted earlier, our data indicates the process of tax convergence accelerating during the period 1970-1985. Since the Lane and Milesi-Ferretti (2007) data only starts in 1970, we miss the period before 1970 when capital tax differences were higher and financial integration was lower. Thus the magnitude of this coefficient likely underestimates the effect of financial integration on tax convergence. However the estimated effect is still economically significant: The median values of the financial openness index in 1970 and 2010 were 0.6 and 5.5, respectively, which suggests for the median country a predicted decline of approximately 5.4 percentage points in the capital tax rate difference with the United States. At the same time, our regression does not control for a number of other domestic factors affecting tax rates that might have been converging over this period, as argued in Slemrod (2004). Nevertheless, the negative and highly statistically significant coefficient on $\mathbb{N N}_{i, t}$ provides suggestive evidence that the process of financial integration played a role in the process of capital tax rate convergence.

Recall that our interest in the convergence of capital taxes was motivated by the trend decline of the all-tax-inclusive risk-sharing wedge with respect to the United States as countries became more financially integrated (Figure 2). Thus, it is interesting to ask: What does the process of financial integration and capital tax convergence documented above imply for the behavior of the risk-sharing wedge? Therefore, to tie the preceding analysis on capital tax convergence back to the evolution of risk-sharing wedges, we run a regression of the following form:

$$
\left|\Gamma_{A, t}^{i, U S}-1\right|=\alpha_{i}+\theta_{I N T}^{\prime} \mathbb{I N} \mathbb{T}_{i, t}+\epsilon_{i, t}
$$

described in detail in the earlier data section, the tax rates used in our analysis are average rates, and not statutory rates or average marginal tax rates, which are often the focus of public finance papers on this topic. The tax rates we use are also calculated differently than Mendoza et al. (1994) who use average (effective) tax rates (see McDaniel, 2009, 2011, for details). Such differences in construction should be kept in mind when comparing our results to previous literature.

${ }^{31}$ We do not report the regression results in a table for brevity. The estimated point coefficient is -0.0113 with a standard error of 0.0025 , a t-statistic of -4.47 and a p-value of 0.001 . The standard errors are clustered at the level of country $i$. 
The dependent variable $\left|\Gamma_{A, t}^{i, U S}-1\right|$ in Equation 16 is the extent to which the all-tax-inclusive risk-sharing wedge of country $i$ with respect to the United States differs from its perfect-risksharing value of 1 . Note that since the perfect-risk-sharing value is $1,\left|\Gamma_{A, t}^{i, U S}-1\right|$ also measures the percentage deviation of the risk-sharing wedge from this value. The point estimate of $\theta_{I N T}^{\prime}$ in the above regression is -0.015 , and it is statistically significant at the $1 \%$ level. ${ }^{32}$ To get a sense of the magnitude of the effect of financial integration on the all-tax-inclusive risk-sharing wedge, we perform the same calculation as before using the median values of the financial openness index in 1970 and 2010. The median country in our sample of 14 OECD countries is predicted to experience a decline of approximately 7.4 percentage points in its risk-sharing wedge with the United States. In comparison, a similar regression with the baseline wedge using $\left|\Gamma_{B, t}^{i, U S}-1\right|$ as the dependent variable predicts a decline in the baseline wedge of approximately 1.8 percentage points. Thus, adjusting for consumption and capital taxes, especially the latter, in the manner suggested by the theory, suggests a decline in risk-sharing wedges that is roughly 4 times larger than the baseline case.

\subsubsection{Discussion}

The analysis in this section suggests that the levels of capital taxes of OECD nations converged to that of the United States, led primarily by declines in the United States rate and increases in a majority of the other countries. This process of convergence took place mostly in the period 1970-1985 amid the growing internationalization and integration of the capital markets of these countries. Some recent papers in the public finance literature, as well as our own results, are therefore suggestive of the United States being a Stackelberg leader in the setting of capital tax rates, which led to capital-tax convergence across countries to the United States in the context of greater global financial openness. ${ }^{33}$ We also showed that a measure of the level of risk sharing that accounts for capital taxes, as suggested by our structural model, registered roughly concurrent declines. While the decline in this measure was mechanically related to capital taxes in a sense, our model provides a sound rationale as to why such a tax adjusted measure is the correct metric to examine when assessing international risk sharing. Financial integration therefore appears to have been associated both with cross-country convergence of capital taxes to the United States' capital tax rate, and as our earlier analysis of risk-sharing wedges showed, greater levels of risk sharing of most countries with the United States. These results corroborate our earlier regression analysis of consumption growth, which showed taxes to be a significant determinant of international risk sharing.

\footnotetext{
${ }^{32}$ Once again, we do not report the regression results in a table for brevity. The estimated standard error is 0.0033 , with a t-statistic of -4.64 . The standard errors are clustered at the level of country $i$.

${ }^{33}$ This is in contrast to a special case of tax convergence, which would be a "race to the bottom" stemming from countries engaging in a Bertrand-style capital-tax setting competition.
} 


\section{Conclusion}

This paper develops an understanding of how, and the extent to which, cross-country differences, yearly fluctuations, and long-term trends in consumption and capital taxes matter for understanding international risk sharing. To the best of our knowledge, this is the first paper in the literature to do so. It is well known that, empirically, a lack of international risk sharing is substantially prevalent in the data as measured by a lack of equalization of consumption growth rates across countries. The degree to which such robust international risk sharing fails to manifest itself empirically is puzzling from the point of view of a standard international business cycle model. Indeed, this model predicts that consumption, or its growth rates, should be highly correlated across countries when risk sharing between countries is substantial.

We examine the impact of taxes from two broad vantage points, regression-based tests and business cycle accounting, by extending an otherwise standard international business cycle model to account for taxes. We find that consumption growth is significantly correlated to fluctuations in the level of capital taxes and the growth rate of consumption taxes, as predicted by our theory. However, risk-sharing regressions suggest that taxes within and across countries explain a much lower fraction of the variation in consumption than does output. Given these two results, we conclude that while taxes alone cannot explain the lack of consumption insurance across countries, they should be controlled for when evaluating the empirical performance of individual theories or frictions that purport to explain international risk sharing, or its failure, over the business cycle.

From a more long-term business cycle accounting perspective, we derive the notion of a risksharing wedge. This wedge captures the extent to which an international real business cycle model's risk-sharing condition fails to hold at any point in time, and therefore allows for a dynamic vantage point of risk sharing. The inclusion of taxes in the operationalized model reveals substantial improvements in the degree of international risk sharing over time, especially since the late 1970s. We find that the downward trend in the risk-sharing wedge has been largely driven by the convergence in cross-country capital tax rates to that of the United States, where the pattern of convergence is consistent with the United States acting as a Stackelberg leader in the setting of capital taxes. This improvement in international risk sharing generally coincides with improvements in financial liberalization, which, in turn, is intimately related to the convergence in capital tax rates. Yet, we also show that this intuitive result is virtually absent when taxes are not incorporated in the analysis. Since different structural frictions introduced into IBC models to explain the failure of risk sharing show up as reduced-form wedges, such theories should attempt to explain the after-tax risk-sharing wedge and its co-evolution with financial integration. As such, we conclude that accounting for taxes, especially capital taxes, is critical for assessing the correct degree of international risk sharing over time. 


\section{Acknowledgements}

The authors are grateful to Charles Engel and Fabrizio Perri for their invaluable editorial guidance, and an anonymous referee for thoughtful suggestions. They are also thankful, without implicating, for helpful comments received during visits to the Board of Governors of the Federal Reserve System, Brown University, the Federal Reserve Bank of Atlanta, the Federal Reserve Bank of Philadelphia, the Federal Reserve Bank of Richmond, McMaster University, and also for insightful discussions with Jean-Louis Arcand, Rex Ghosh, Mathias Hoffmann, Matteo Maggiori, Enrique Mendoza, Marco Pagano, Giorgio Primiceri, Vincenzo Quadrini, Assaf Razin, Joel Slemrod, Martin Uribe, Lore Vandewalle, Jing Zhang, and especially, Cédric Tille. Caitlin McGonnigal, Teyanna Munyan, and Jingjing Xia provided excellent research assistance. The views in this paper are solely the responsibility of the authors and should not be interpreted as reflecting the views of the Board of Governors of the Federal Reserve System or of any other person associated with the Federal Reserve System, or of the United States Treasury Department.

\section{References}

R. Altshuler and T. J. Goodspeed. Follow the leader? evidence on european and u.s. tax competition. Public Finance Review, 43(4):485-504, 2015.

M. J. Artis and M. Hoffmann. Financial globalization, international business cycles and consumption risk sharing. The Scandinavian Journal of Economics, 110(3):447-471, 2008.

P. Asdrubali, B. E. Sørensen, and O. Yosha. Channels of interstate risk sharing: United states 1963-1990. The Quarterly Journal of Economics, 111(4):1081-1110, 1996.

D. Backus, C. Coleman, A. Ferriere, and S. Lyon. Pareto weights as wedges in two-country models. Journal of Economic Dynamics and Control, 2016.

D. K. Backus and G. W. Smith. Consumption and real exchange rates in dynamic economies with non-traded goods. Journal of International Economics, 35, 1993.

D. K. Backus, P. Kehoe, and F. Kydland. International real business cycles. Journal of Political Economy, 1992.

D. K. Backus, P. J. Kehoe, and F. E. Kydland. Dynamics of the trade balance and the terms of trade: The J-Curve? The American Economic Review, 84(1), 1994.

Y. Bai and J. Zhang. Solving the feldstein-horioka puzzle with financial frictions. Econometrica, pages $603-632,2010$. 
Y. Bai and J. Zhang. Financial integration and international risk sharing. Journal of International Economics, 86(1):17-32, 2012.

M. Baxter and M. J. Crucini. Business cycles and the asset structure of foreign trade. International Economic Review, 1995.

J. Bengui, E. G. Mendoza, and V. Quadrini. Capital mobility and international sharing of cyclical risk. Journal of Monetary Economics, 60(1):42-62, 2013.

S. Bucovetsky. Asymmetric tax competition. National Tax Journal, 30(2):167-181, 1991.

D. Carey and J. Rabesona. Tax ratios on labour and capital income and on consumption. OECD Economic Studies, 35, 2002.

V. Chari, P. Kehoe, and E. McGrattan. Can sticky price models generate volatile and persistent real exchange rates? The Review of Economic Studies, 69(3), 2002.

V. V. Chari, P. J. Kehoe, and E. R. McGrattan. Business cycle accounting. Econometrica, 75(3), 2007.

M. D. Chinn and H. Ito. What matters for financial development? capital controls, institutions, and interactions. Journal of Development Economics, 81(1):163-192, 2006.

M. D. Chinn and H. Ito. A new measure of financial openness. Journal of Comparative Policy Analysis, 10(3):309-322, 2008.

J. H. Cochrane. A simple test of consumption insurance. Journal of political economy, pages 957-976, 1991.

N. Coeurdacier. Do trade costs in goods market lead to home bias in equities? Journal of International Economics, 77(1):86-100, 2009.

N. Coeurdacier, E. Faraglia, and F. Gomes. The international taxation of capital. Society for Economic Dynamics Meeting Papers, (440), 2012.

G. Corsetti, L. Dedola, and S. Leduc. International risk sharing and the transmission of productivity shocks. The Review of Economic Studies, 75(2):443-473, 2008.

M. P. Devereux. Developments in the taxation of corporate profit in the oecd since 1965: Rates, bases and revenues. Oxford University Centre for Business Taxation WP 07/04, 2007.

M. P. Devereux and S. Loretz. What do we know about corporate tax competition? National Tax Journal, 66(3):745-774, 2013. 
M. P. Devereux, B. Lockwood, and M. Redoano. Do countries compete over corporate tax rates? Journal of Public Economics, 92(5):1210-1235, 2008.

C. Engel and J. H. Rogers. Expected consumption growth from cross-country surveys: implications for assessing international capital markets. IMF Staff Papers, 56(3):543-573, 2009.

B. Epstein, R. Mukherjee, and S. P. Ramnath. Taxes and international risk sharing. Federal Reserve Board International Finance Discussion Paper, 2014-1110, 2014.

R. Flood, N. Marion, and A. Matsumoto. International risk sharing during the globalization era. Canadian Journal of Economics, 45(2), 2012.

J. Gali, M. Gertler, and J. D. Lopez-Salido. Markups, gaps, and the welfare costs of business fluctuations. The review of economics and statistics, 89(1):44-59, 2007.

R. Gordon. Can capital income taxes survive in open economies? The Journal of Finance, 47(3): 1159-1180, 1992.

R. H. Gordon and J. R. Hines. Handbook of Public Economics, volume 4, chapter International Taxation, pages 1935-1995. Elsevier, Amsterdam, The Netherlands, 2002.

H. Grubert. International Taxation and Multinational Activity, chapter Tax Planning by Companies and Tax Competition by Governments: Is There Evidence of Changes in Behavior?, pages 113139. University of Chicago Press, Chicago and London, 2001.

J. R. Hines. Taxing Corporate Income, chapter Corporate Taxation and International Competition, pages 268-295. Cambridge University Press, Cambridge, UK, 2007.

M. Hoffmann. The lack of international consumption risk sharing: Can inflation differentials and trading costs help explain the puzzle? Open Economies Review, 19(2):183-201, 2008.

J. Imbs. The real effects of financial integration. Journal of International Economics, 68(2):296-324, 2006.

L. Karabarbounis. The labor wedge: Mrs vs. mpn. Review of Economic Dynamics, 17(2), 2014a.

L. Karabarbounis. Home production, labor wedges, and international business cycles. Journal of Monetary Economics, 64, 2014b.

P. J. Kehoe and F. Perri. International business cycles with endogenous incomplete markets. Econometrica, 70(3), 2002.

M. A. Kose, E. S. Prasad, and M. E. Terrones. Does financial globalization promote risk sharing? Journal of Development Economics, 89(2):258-270, 2009. 
P. R. Lane and G. M. Milesi-Ferretti. The external wealth of nations mark ii: Revised and extended estimates of foreign assets and liabilities, 1970-2004. Journal of international Economics, 73(2): 223-250, 2007.

K. K. Lewis. What can explain the apparent lack of international consumption risk sharing? Journal of Political Economy, 104:267-297, 1996.

B. J. Mace. Full insurance in the presence of aggregate uncertainty. Journal of Political Economy, pages 928-956, 1991.

C. McDaniel. Average tax rates on consumption, investment, labor and capital in the OECD 1950-2003. Unpublished Manuscript, 2009.

C. McDaniel. Forces shaping hours worked in the oecd, 19602004. American Economic Journal: Macroeconomics, 3(4):27-52, 2011.

E. Mendoza and L. Tesar. The international ramifications of tax reforms: supply-side economics in a global economy. The American Economic Review, 88(1), 1998.

E. Mendoza, A. Razin, and L. Tesar. Effective tax rates in macroeconomics:: Cross-country estimates of tax rates on factor incomes and consumption. Journal of Monetary Economics, 34(3), 1994.

E. G. Mendoza and L. L. Tesar. Why hasnt tax competition triggered a race to the bottom? some quantitative lessons from the eu. Journal of Monetary Economics, 52(1):163-204, 2005.

E. G. Mendoza, L. L. Tesar, and J. Zhang. Saving europe?: The unpleasant arithmetic of fiscal austerity in integrated economies. University of Michigan Working Paper, 2013.

L. Ohanian, A. Raffo, and R. Rogerson. Long-term changes in labor supply and taxes: Evidence from oecd countries, 1956-2004. Journal of Monetary Economics, 55(8):1353-1362, 2008.

E. C. Prescott. Why do americans work so much more than europeans? Federal Reserve Bank of Minneapolis Quarterly Review, 28(1):2-13, 2004.

K. S. Ragan. Taxes and time use: Fiscal policy in a household production model. American Economic Journal: Macroeconomics, 5(1):168-192, 2013.

J. D. Sachs and A. M. Warner. Economic reform and the process of global integration. Brookings Papers on Economic Activity, 26(1):1-118, 1995.

J. Slemrod. Are corporate tax rates, or countries, converging? Journal of Public Economics, 88 (6):1169-1186, 2004. 
A. C. Stockman and L. L. Tesar. Tastes and technology in a two-country model of the business cycle: Explaining international comovements. The American Economic Review, 85:168-185, 1995.

R. M. Townsend. Risk and insurance in village india. Econometrica: Journal of the Econometric Society, pages 539-591, 1994.

G. R. Zodrow. Capital mobility and capital tax competition. National Tax Journal, 63(4):865-901, 2010. 
Table 1: Correlation of Per capita Consumption Growth Rates Across Countries

\begin{tabular}{llllllllllllllll}
\hline \hline & & & & & & & & & & & & & & \\
& Aus & Aut & Bel & Can & Fin & Fra & Ger & Ita & Jap & Nld & Spa & Swe & Swi & UK & USA \\
\hline Aus & 1.00 & & & & & & & & & & & & & \\
Aut & 0.05 & 1.00 & & & & & & & & & & & & \\
Bel & 0.24 & 0.65 & 1.00 & & & & & & & & & & & \\
Can & 0.28 & 0.16 & 0.26 & 1.00 & & & & & & & & & & & \\
Fin & 0.28 & 0.29 & 0.32 & 0.34 & 1.00 & & & & & & & & & & \\
Fra & 0.23 & 0.69 & 0.69 & 0.26 & 0.50 & 1.00 & & & & & & & & \\
Ger & -0.09 & 0.64 & 0.58 & 0.25 & 0.31 & 0.71 & 1.00 & & & & & & & \\
Ita & 0.19 & 0.58 & 0.70 & 0.14 & 0.38 & 0.72 & 0.56 & 1.00 & & & & & & \\
Jap & 0.04 & 0.61 & 0.60 & 0.08 & 0.40 & 0.77 & 0.63 & 0.64 & 1.00 & & & & & \\
Nld & 0.40 & 0.46 & 0.54 & 0.36 & 0.20 & 0.57 & 0.61 & 0.47 & 0.34 & 1.00 & & & & \\
Spa & 0.32 & 0.71 & 0.66 & 0.41 & 0.44 & 0.80 & 0.59 & 0.77 & 0.61 & 0.57 & 1.00 & & & \\
Swe & 0.34 & 0.33 & 0.41 & 0.46 & 0.56 & 0.54 & 0.39 & 0.44 & 0.29 & 0.35 & 0.64 & 1.00 & & \\
Swi & 0.03 & 0.59 & 0.61 & 0.29 & 0.44 & 0.72 & 0.72 & 0.66 & 0.61 & 0.51 & 0.66 & 0.36 & 1.00 & \\
UK & 0.23 & 0.15 & 0.31 & 0.46 & 0.40 & 0.33 & 0.15 & 0.26 & 0.32 & 0.19 & 0.39 & 0.32 & 0.31 & 1.00 \\
USA & 0.19 & 0.22 & 0.22 & 0.57 & 0.25 & 0.37 & 0.36 & 0.16 & 0.30 & 0.38 & 0.37 & 0.28 & 0.36 & 0.64 & 1.00 \\
\hline
\end{tabular}

Notes: Pairwise correlations are calculated for yearly per capita country consumption growth. Data Source: OECD. 
Australia

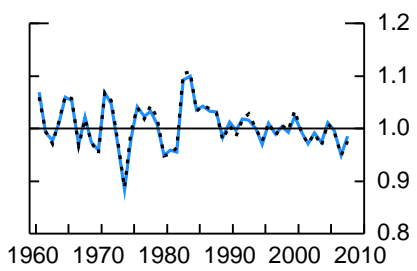

Canada

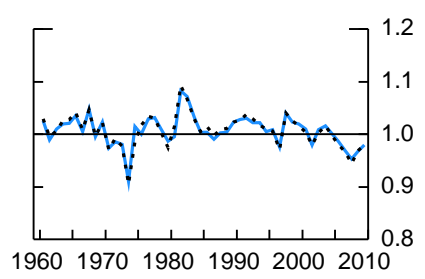

Germany

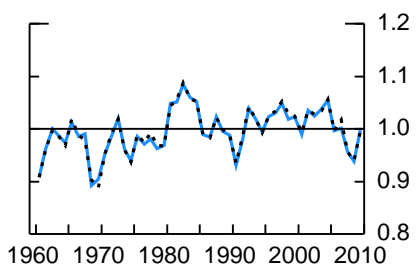

Netherlands

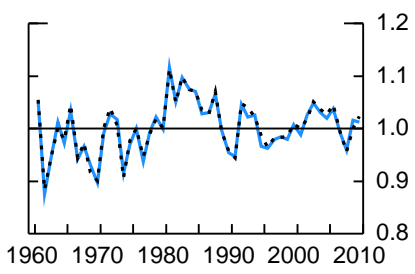

Switzerland

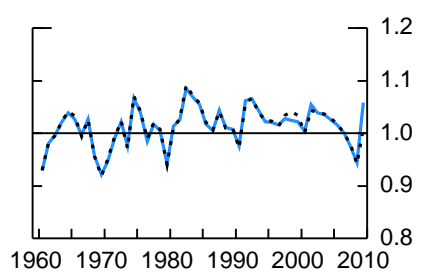

Austria

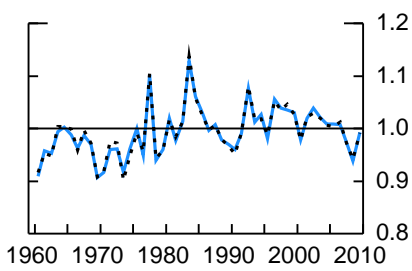

Finland

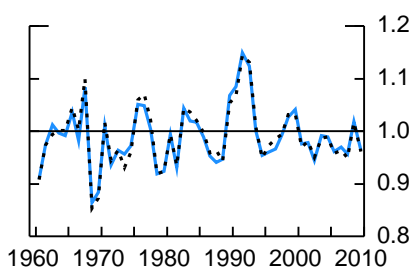

Italy

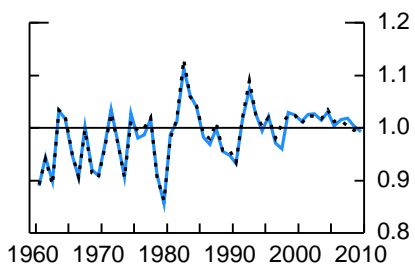

Spain

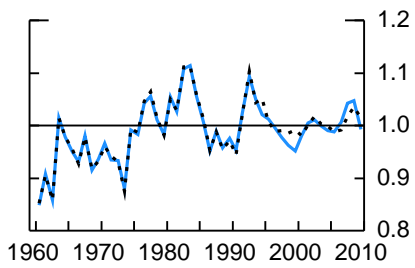

UK

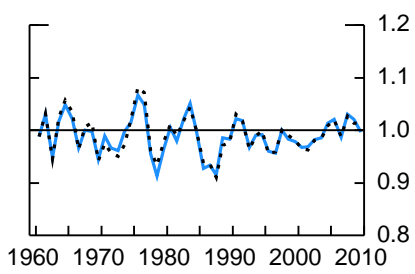

Belgium

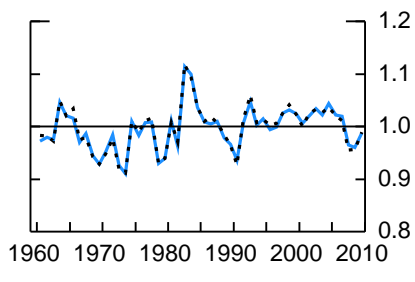

France

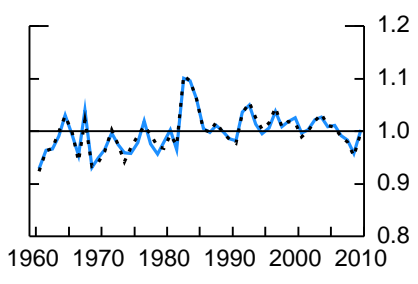

Japan

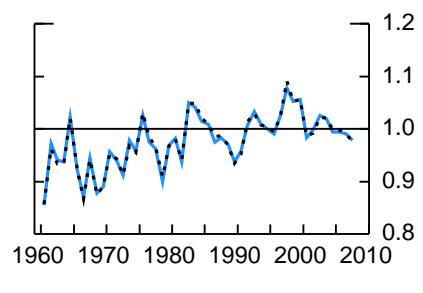

Sweden

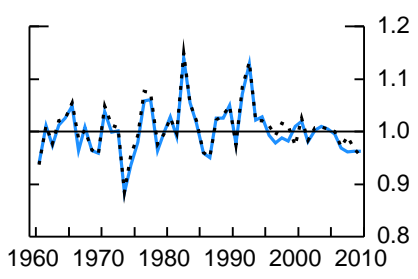

.... No-tax Risk Wedge

_ Consumption-tax Only Risk Wedge

Figure 1: Baseline and Consumption Tax Adjusted Wedges. Data sources: OECD and McDaniel (2009). 
Australia

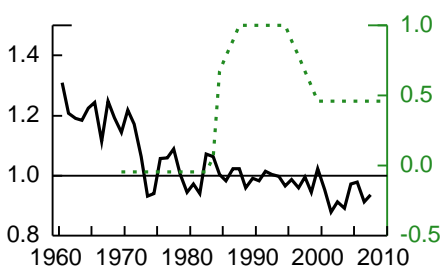

Canada

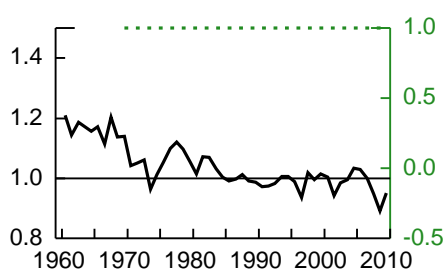

Germany

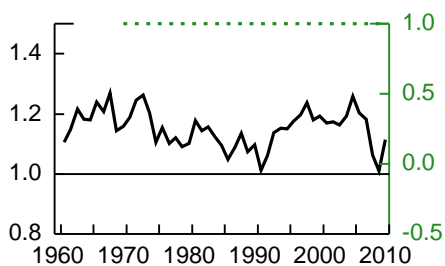

Netherlands

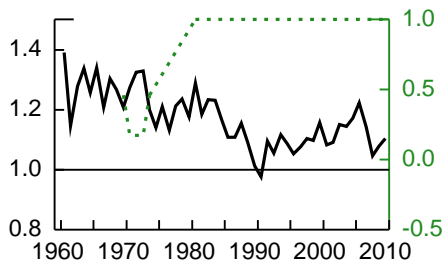

Switzerland

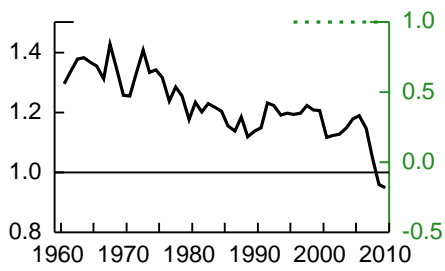

Austria

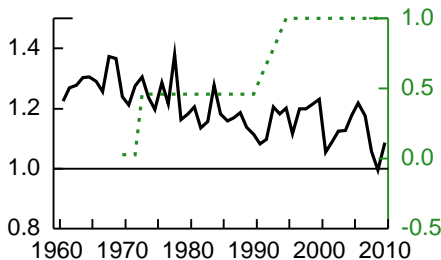

Finland

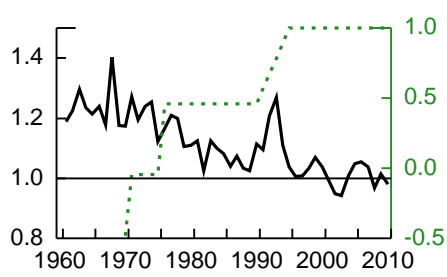

Italy

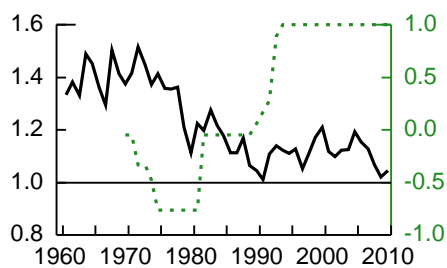

Spain

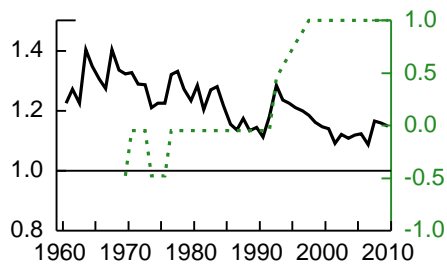

UK

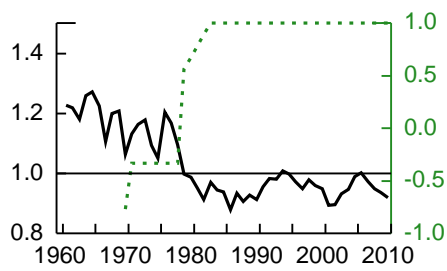

Belgium

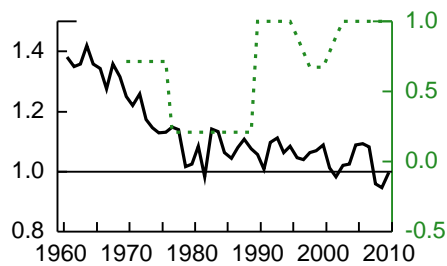

France

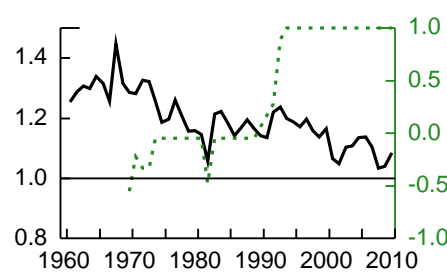

Japan

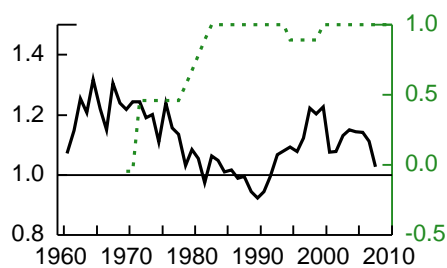

Sweden

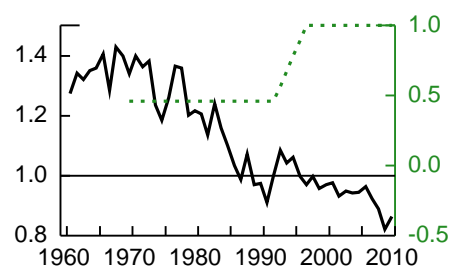

- Tax-inclusive Risk Wedge (left axis) .... Chinn-Ito Index relative to the United States (right axis)

Figure 2: Wedge Adjusted for All Taxes and Financial Openness. Data sources: OECD, McDaniel (2009), and Chinn and Ito (2006) 


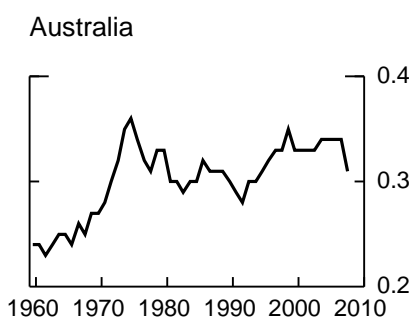

Canada

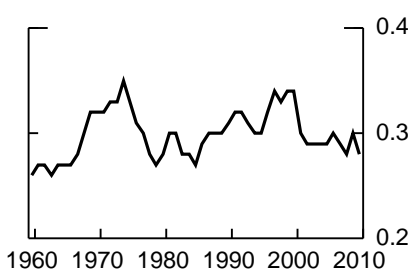

Germany

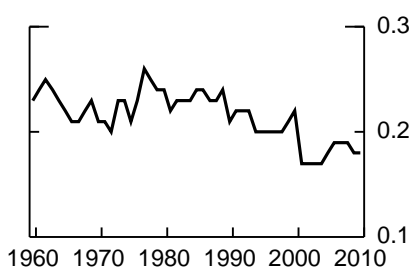

Netherlands

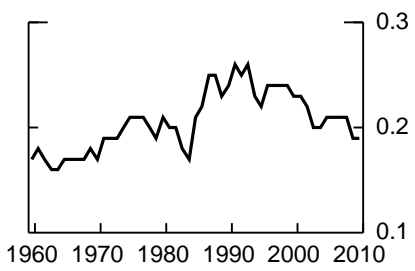

Switzerland

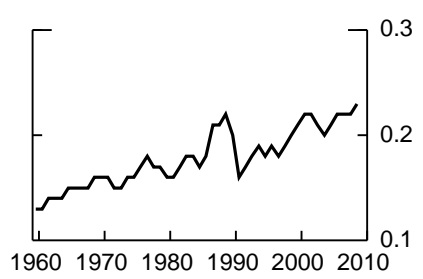

Austria

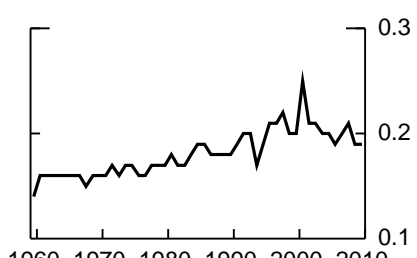

Finland

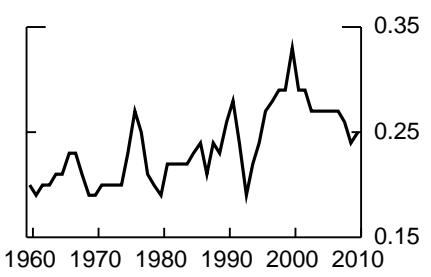

Italy

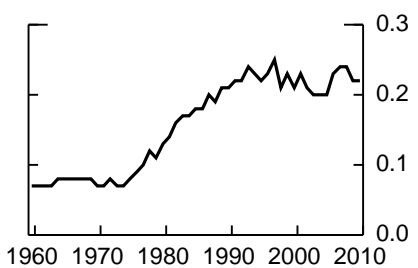

Spain

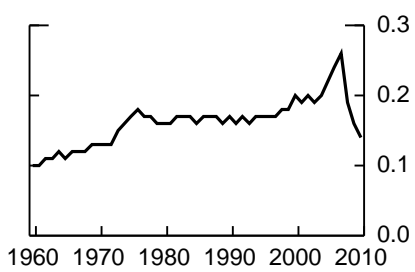

UK

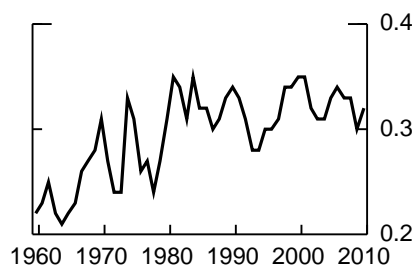

Belgium

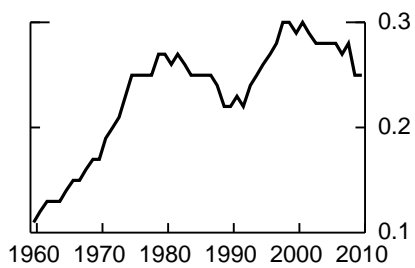

France

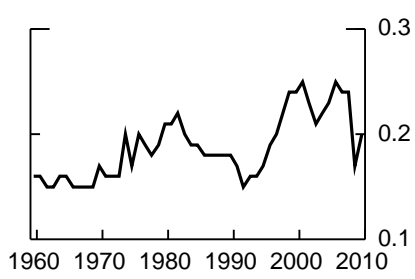

Japan

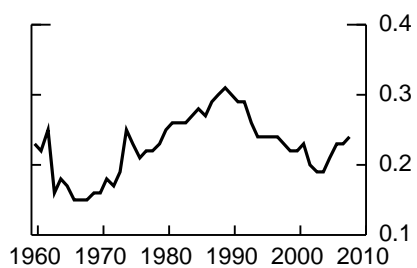

Sweden

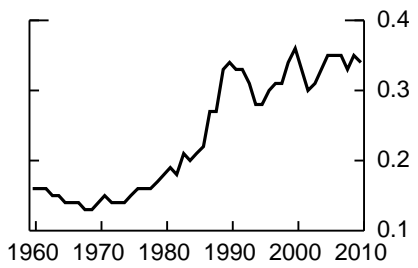

US

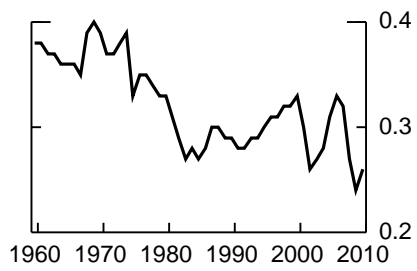

Figure 3: Average Capital Tax Rates 1960-2010. Data source: McDaniel (2009). 


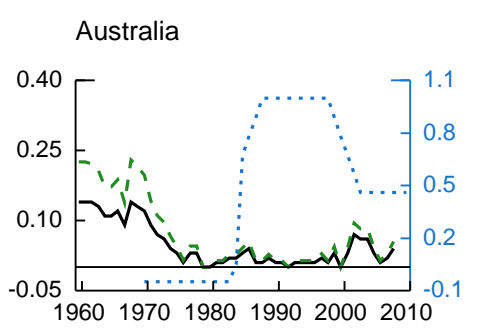

Canada

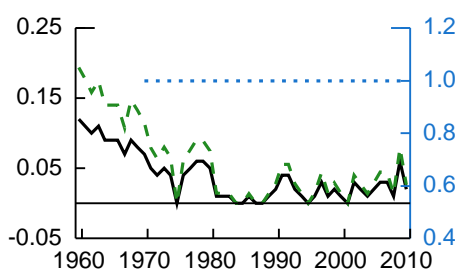

Germany

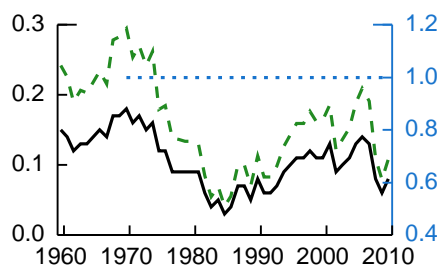

Netherlands

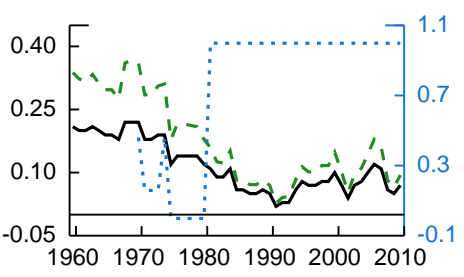

Switzerland

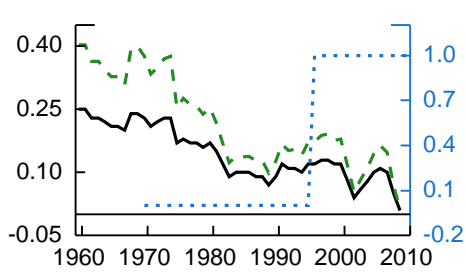

Austria

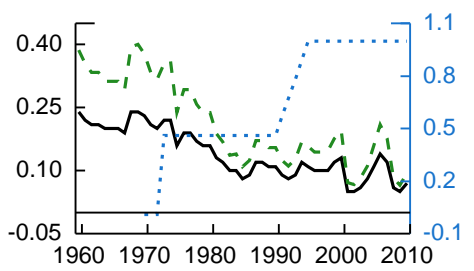

Finland

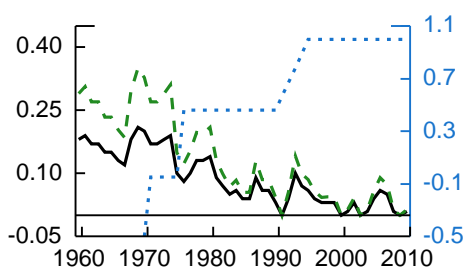

Italy

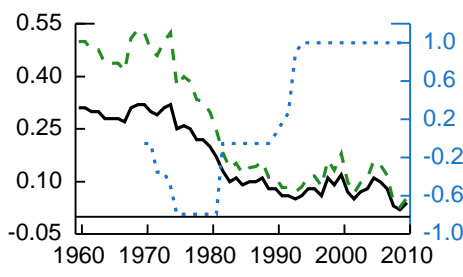

Spain

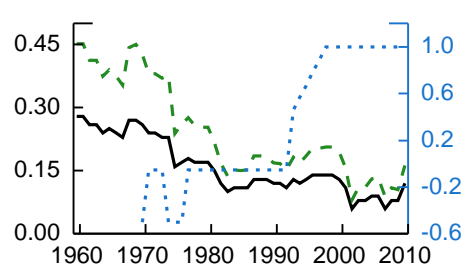

UK

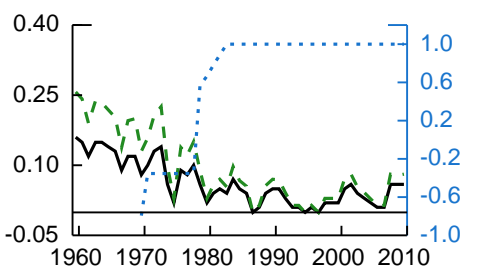

Belgium

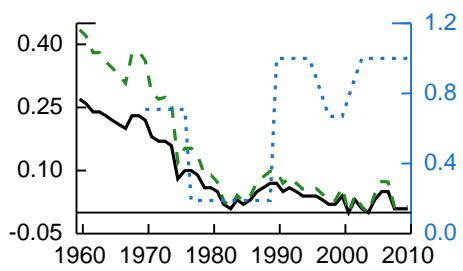

France

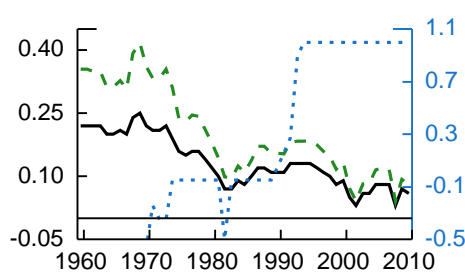

Japan

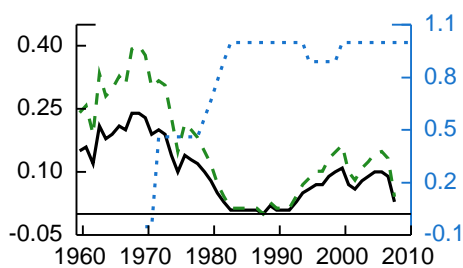

Sweden

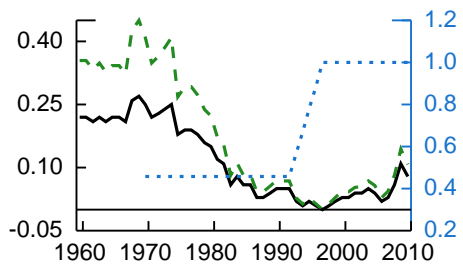

- - Absolute Value of Deviation of Capital Tax Wedge . . . - Chin-Ito Index

Figure 4: Absolute Difference and Wedges (w.r.t. US) of Average Capital Tax Rates 1960-2010. Data source: McDaniel (2009). 
Table 2: The Sensitivity of Domestic Consumption Growth to Domestic Tax Rates: Benchmark (1960-2010)

\begin{tabular}{|c|c|c|c|c|}
\hline Variable Name & No Tax & With $\tau^{c}$ & With $\tau^{k}$ & $\operatorname{Both} \tau^{c}, \tau^{k}$ \\
\hline$X_{i t}$ & $\begin{array}{c}0.768^{* * *} \\
(0.04)\end{array}$ & $\begin{array}{c}0.766^{* * *} \\
(0.04)\end{array}$ & $\begin{array}{c}0.772^{* * *} \\
(0.04)\end{array}$ & $\begin{array}{c}0.770^{* * * *} \\
(0.04)\end{array}$ \\
\hline$\Delta\left(1+\tau_{i t}^{c}\right)$ & & $\begin{array}{c}-0.161^{*} \\
(0.08)\end{array}$ & & $\begin{array}{c}-0.160^{* *} \\
(0.07)\end{array}$ \\
\hline $\ln \left(1-\tau_{i t}^{k}\right)$ & & & $\begin{array}{c}-0.013 \\
(0.01)\end{array}$ & $\begin{array}{c}-0.013 \\
(0.01)\end{array}$ \\
\hline$R^{2}$ & 0.7476 & 0.7503 & 0.7483 & 0.7510 \\
\hline No. Obs. & 745 & 745 & 745 & 745 \\
\hline Country Fixed Effects & Yes & Yes & Yes & Yes \\
\hline Year Fixed Effects & Yes & Yes & Yes & Yes \\
\hline
\end{tabular}

Notes: Coefficient estimates of Equation 11. Dependent variable is country consumption growth between periods $t$ and $t-1$. Independent variables are the growth rates of per capita GDP $(X)$ and the gross consumption tax rate $\left(1+\tau^{c}\right)$, and the natural logarithm of $\left(1-\tau^{k}\right)$, where $\tau^{k}$ is the capital income tax rate. Robust standard errors, clustered at the country level, in parentheses. Coefficients marked $* * *, * *$ and $*$ are significant at $1 \%, 5 \%$ and $10 \%$, respectively. Data Sources: OECD and McDaniel (2009). 
Table 3: The Sensitivity of International Consumption Growth Differentials to International Tax Rate Differentials: Benchmark (1960-2010)

\begin{tabular}{|c|c|c|c|c|}
\hline Variable Name & No Tax & With $\tau^{c}$ & With $\tau^{k}$ & With $\tau^{c}, \tau^{k}$ \\
\hline$X_{i t}-X_{j t}$ & $\begin{array}{c}0.764^{* * * *} \\
(0.03)\end{array}$ & $\begin{array}{c}0.750^{* * *} \\
(0.03)\end{array}$ & $\begin{array}{c}0.741^{* * * *} \\
(0.02)\end{array}$ & $\begin{array}{c}0.726^{* * *} \\
(0.02)\end{array}$ \\
\hline$\Delta\left(1+\tau_{i t}^{c}\right)-\Delta\left(1+\tau_{j t}^{c}\right)$ & & $\begin{array}{c}-0.248^{* * *} \\
(0.06)\end{array}$ & & $\begin{array}{c}-0.255^{* * *} \\
(0.06)\end{array}$ \\
\hline $\ln \left(1-\tau_{i t}^{k}\right)-\ln \left(1-\tau_{j t}^{k}\right)$ & & & $\begin{array}{c}0.017^{* *} \\
(0.01)\end{array}$ & $\begin{array}{c}0.018^{* *} \\
(0.01)\end{array}$ \\
\hline$R^{2}$ & 0.6315 & 0.6388 & 0.6364 & 0.644 \\
\hline No. Obs. & 695 & 695 & 695 & 695 \\
\hline Country Pair Fixed Effects & Yes & Yes & Yes & Yes \\
\hline Year Fixed Effects & No & No & No & No \\
\hline
\end{tabular}

Notes: Coefficient estimates of Equation 12. Dependent variable is the difference between country $i$ and $j$ of consumption growth between periods $t$ and $t-1$. Country $j$ is always the United States. Independent variables are the difference between country $i$ and $j$ of the growth rates of per capita GDP $(X)$ and the gross consumption tax rate $\left(1+\tau^{c}\right)$, and the difference between country $i$ and $j$ of the natural logarithm of $\left(1-\tau^{k}\right)$, where $\tau^{k}$ is the capital income tax rate. Robust standard errors, clustered at the country level, in parentheses. Coefficients marked $* * *, * *$ and $*$ are significant at 1\%, 5\% and 10\%, respectively. Data Sources: OECD and McDaniel (2009). 
Table 4: The Sensitivity of Domestic Consumption Growth to Domestic Tax Rates Controlling for Financial Integration: 1970-2010

\begin{tabular}{|c|c|c|c|c|c|}
\hline$\underline{\text { Variable Name }}$ & \multicolumn{2}{|c|}{$\underline{\text { No Taxes }}$} & $\underline{\text { With } \tau^{c}}$ & $\underline{\text { With } \tau^{k}}$ & With $\tau^{c}, \tau^{k}$ \\
\hline$X_{i t}$ & $\begin{array}{c}0.731^{* * *} \\
(0.04)\end{array}$ & $\begin{array}{c}0.761^{* * *} \\
(0.06)\end{array}$ & $\begin{array}{c}0.761^{* * *} \\
(0.06)\end{array}$ & $\begin{array}{c}0.769^{* * *} \\
(0.06)\end{array}$ & $\begin{array}{c}0.769^{* * *} \\
(0.06)\end{array}$ \\
\hline $\mathbb{I N T} \mathbb{T}_{i t}$ & & $\begin{array}{c}-0.001^{* *} \\
(0.00)\end{array}$ & $\begin{array}{c}-0.001^{* *} \\
(0.00)\end{array}$ & $\begin{array}{c}-0.002^{* *} \\
(0.00)\end{array}$ & $\begin{array}{c}-0.002^{* *} \\
(0.00)\end{array}$ \\
\hline$X_{i t} \times \mathbb{I N} \mathbb{T}_{i t}$ & & $\begin{array}{c}-0.014 \\
(0.02)\end{array}$ & $\begin{array}{l}-0.015 \\
(0.02)\end{array}$ & $\begin{array}{c}-0.015 \\
(0.02)\end{array}$ & $\begin{array}{l}-0.016 \\
(0.02)\end{array}$ \\
\hline$\Delta\left(1+\tau_{i t}^{c}\right)$ & & & $\begin{array}{l}-0.095 \\
(0.07)\end{array}$ & & $\begin{array}{l}-0.092 \\
(0.07)\end{array}$ \\
\hline $\ln \left(1-\tau_{i t}^{k}\right)$ & & & & $\begin{array}{c}-0.018^{*} \\
(0.01)\end{array}$ & $\begin{array}{c}-0.017^{*} \\
(0.01)\end{array}$ \\
\hline$R^{2}$ & 0.7047 & 0.7108 & 0.7120 & 0.7122 & 0.7133 \\
\hline No. Obs. & 610 & 610 & 610 & 610 & 610 \\
\hline Country Fixed Effects & Yes & Yes & Yes & Yes & Yes \\
\hline Year Fixed Effects & Yes & Yes & Yes & Yes & Yes \\
\hline
\end{tabular}

Notes: Coefficient estimates of Equation 13. Dependent variable is country consumption growth between periods $t$ and $t-1$. Independent variables are the growth rates of per capita GDP $(X)$ and the gross consumption tax rate $\left(1+\tau^{c}\right)$, the natural logarithm of $\left(1-\tau^{k}\right)$, where $\tau^{k}$ is the capital income tax rate, the measure of financial openness $\mathbb{N N T}_{i t}$ described in the text, and its interaction with per capita GDP growth. Robust standard errors, clustered at the country level, in parentheses. Coefficients marked $* * *, * *$, and $*$ are significant at $1 \%, 5 \%$, and $10 \%$ respectively. Data Sources: OECD, Lane and Milesi-Ferretti (2007) and McDaniel (2009). 
Table 5: The Sensitivity of International Consumption Growth Differentials to International Tax Rate Differentials Controlling for Financial Integration: 1978-2010

\begin{tabular}{|c|c|c|c|c|c|}
\hline Variable Name & \multicolumn{2}{|c|}{ No Taxes } & With $\tau^{c}$ & With $\tau^{k}$ & With $\tau^{c}, \tau^{k}$ \\
\hline$X_{i t}-X_{j t}$ & $\begin{array}{c}0.747^{* * *} \\
(0.03)\end{array}$ & $\begin{array}{c}0.772^{* * *} \\
(0.03)\end{array}$ & $\begin{array}{c}0.770^{* * *} \\
(0.03)\end{array}$ & $\begin{array}{c}0.775^{* * *} \\
(0.03)\end{array}$ & $\begin{array}{c}0.772^{* * *} \\
(0.03)\end{array}$ \\
\hline $\mathbb{F}_{i j, t}$ & & $\begin{array}{c}-0.119^{* * *} \\
(0.03)\end{array}$ & $\begin{array}{c}-0.128^{* * *} \\
(0.03)\end{array}$ & $\begin{array}{c}-0.126^{* * *} \\
(0.03)\end{array}$ & $\begin{array}{c}-0.132^{* * *} \\
(0.03)\end{array}$ \\
\hline$\left(X_{i t}-X_{j t}\right) \times \mathbb{F}_{i j, t}$ & & $\begin{array}{c}-3.425^{* *} \\
(1.41)\end{array}$ & $\begin{array}{c}-3.531^{* *} \\
(1.42)\end{array}$ & $\begin{array}{c}-3.474^{* *} \\
(1.43)\end{array}$ & $\begin{array}{c}-3.560^{* *} \\
(1.45)\end{array}$ \\
\hline$\Delta\left(1+\tau_{i t}^{c}\right)-\Delta\left(1+\tau_{j t}^{c}\right)$ & & & $\begin{array}{c}-0.172^{* * *} \\
(0.05)\end{array}$ & & $\begin{array}{c}-0.164^{* *} \\
(0.06)\end{array}$ \\
\hline $\ln \left(1-\tau_{i t}^{k}\right)-\ln \left(1-\tau_{j t}^{k}\right)$ & & & & $\begin{array}{c}-0.013 \\
(0.02)\end{array}$ & $\begin{array}{r}-0.009 \\
(0.02)\end{array}$ \\
\hline$R^{2}$ & 0.5407 & 0.5477 & 0.5526 & 0.5487 & 0.5531 \\
\hline No. Obs. & 424 & 424 & 424 & 424 & 424 \\
\hline Country Pair Fixed Effects & Yes & Yes & Yes & Yes & Yes \\
\hline Year Fixed Effects & No & No & No & No & No \\
\hline
\end{tabular}

Notes: Coefficient estimates of Equation 14. Dependent variable is the difference between country $i$ and $j$ of consumption growth between periods $t$ and $t-1$. Country $j$ is always the United States. Independent variables are the difference between country $i$ and $j$ of the growth rates of per capita GDP $(X)$ and the gross consumption tax rate $\left(1+\tau^{c}\right)$, the difference between country $i$ and $j$ of the natural logarithm of $\left(1-\tau^{k}\right)$, where $\tau^{k}$ is the capital income tax rate, the measure of bilateral financial integration $\mathbb{F}_{i j, t}$ described in the text, and its interaction with per capita GDP growth differentials. Robust standard errors, clustered at the country level, in parentheses. Coefficients marked $* * *, * *$ and $*$ are significant at $1 \%, 5 \%$ and $10 \%$, respectively. Data Sources: OECD, McDaniel (2009) and BIS. 
Table 6: Convergence of Capital Tax Rates

\begin{tabular}{|c|c|c|c|c|}
\hline \multirow[b]{2}{*}{$\underline{\text { Period }}$} & \multicolumn{2}{|c|}{ Abs. Diff. With US Only } & \multicolumn{2}{|c|}{ Abs. Diff. Excl. US } \\
\hline & $\underline{\text { Mean }}$ & $\underline{\text { Std. Dev. }}$ & $\underline{\text { Mean }}$ & $\underline{\text { Std. Dev. }}$ \\
\hline 1961-1965 & 0.1915 & 0.0553 & 0.0655 & 0.0448 \\
\hline 1966-1970 & 0.1960 & 0.0619 & 0.0696 & 0.0526 \\
\hline 1971-1975 & 0.1658 & 0.0723 & 0.0808 & 0.0611 \\
\hline 1976-1980 & 0.1231 & 0.0588 & 0.0705 & 0.0481 \\
\hline 1981-1985 & 0.0677 & 0.0427 & 0.0635 & 0.0441 \\
\hline 1986-1990 & 0.0627 & 0.0403 & 0.0637 & 0.0434 \\
\hline 1991-1995 & 0.0619 & 0.0424 & 0.0644 & 0.0425 \\
\hline 1996-2000 & 0.0675 & 0.0468 & 0.0674 & 0.0463 \\
\hline 2001-2005 & 0.0575 & 0.0328 & 0.0639 & 0.0454 \\
\hline 2006-2010 & 0.0641 & 0.0485 & 0.0724 & 0.0589 \\
\hline
\end{tabular}

Notes: Mean and standard deviation of the absolute value of the capital tax rate differential between country $i$ and $j,\left|\tau_{i}^{k}-\tau_{\mathrm{j}}^{k}\right|$. Columns 1 and 2 for United States as country $j$. Columns 3 and 4 for all bilateral country pairs where country $j$ is not the United States. Mean and standard deviation are calculated over bilateral country pairs and the five year interval listed on leftmost column. Data Source: McDaniel (2009). 